\title{
Restrictions on export of used EEE
}

A study on the legal possibilities to restrict exports of used electric and electronic equipment

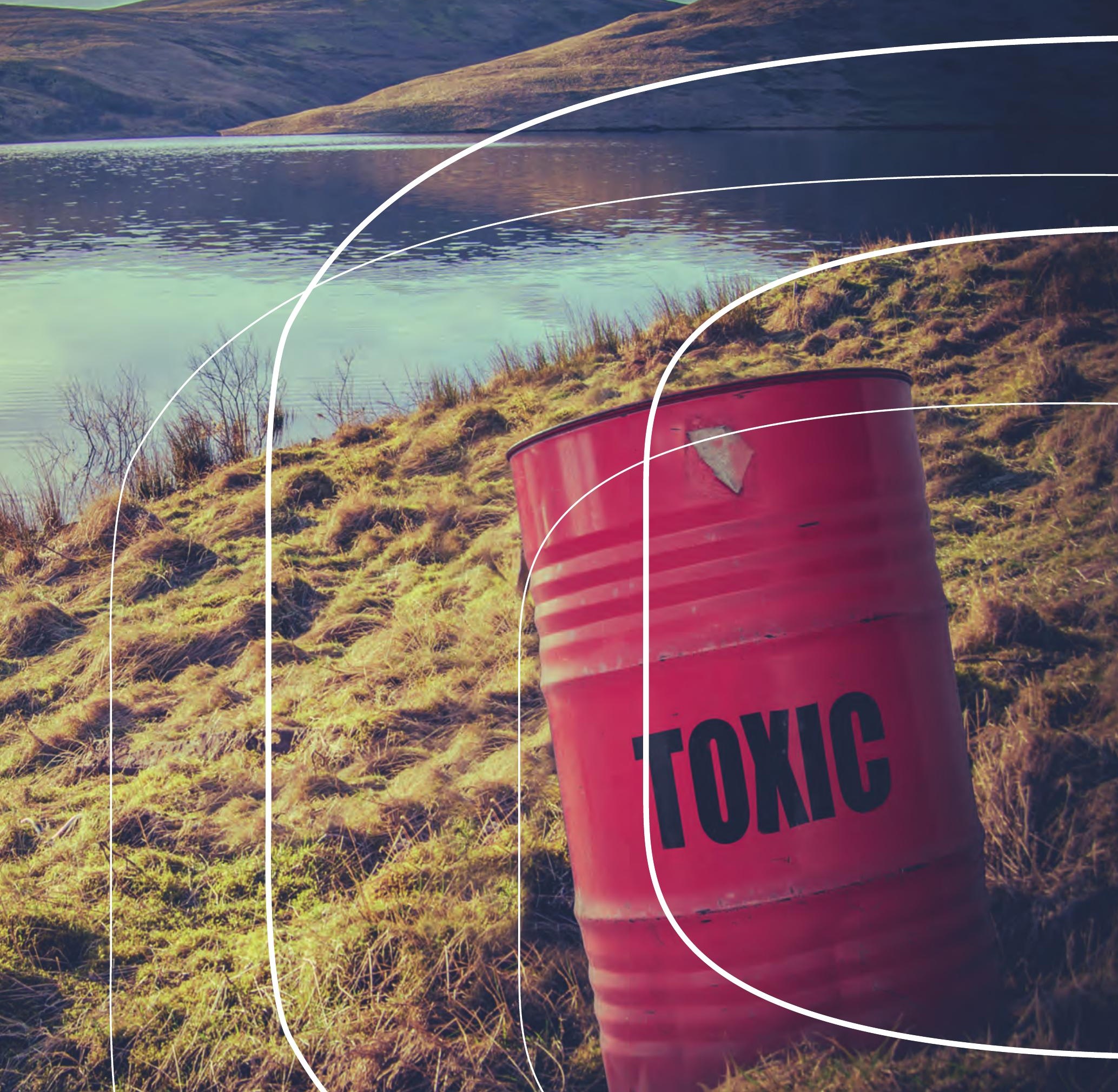


2 norden 



\section{Restrictions on export of used EEE}

A study on the legal possibilities to restrict exports of used electric and electronic equipment

Jacob Brandt and Jacob Schall Holberg, Bech-Bruun Law Firm

TemaNord 2015:581 
Restrictions on export of used EEE

A study on the legal possibilities to restrict exports of used electric and electronic equipment

Jacob Brandt and Jacob Schall Holberg, Bech-Bruun Law Firm

ISBN 978-92-893-4419-7 (PRINT)

ISBN 978-92-893-4420-3 (PDF)

ISBN 978-92-893-4421-0 (EPUB)

http://dx.doi.org/10.6027/TN2015-581

TemaNord 2015:581

ISSN 0908-6692

C) Nordic Council of Ministers 2015

Layout: Hanne Lebech

Cover photo: ImageSelect

Print: Rosendahls-Schultz Grafisk

Printed in Denmark

This publication has been published with financial support by the Nordic Council of Ministers. However, the contents of this publication do not necessarily reflect the views, policies or recommendations of the Nordic Council of Ministers.

\section{www.norden.org/nordpub}

\section{Nordic co-operation}

Nordic co-operation is one of the world's most extensive forms of regional collaboration, involving Denmark, Finland, Iceland, Norway, Sweden, and the Faroe Islands, Greenland, and Åland.

Nordic co-operation has firm traditions in politics, the economy, and culture. It plays an important role in European and international collaboration, and aims at creating a strong Nordic community in a strong Europe.

Nordic co-operation seeks to safeguard Nordic and regional interests and principles in the global community. Common Nordic values help the region solidify its position as one of the world's most innovative and competitive.

\section{Nordic Council of Ministers}

Ved Stranden 18

DK-1061 Copenhagen K

Phone (+45) 33960200

www.norden.org 


\section{Contents}

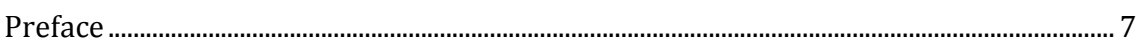

Purpose

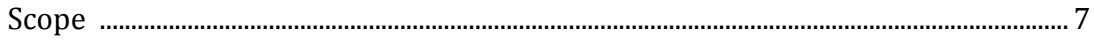

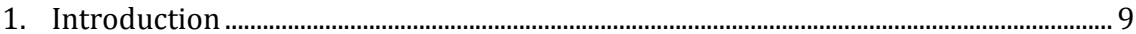

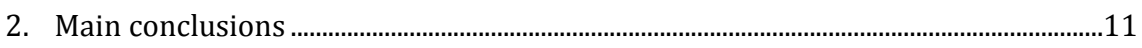

2.1 Waste regulation as a mean .........................................................................11

2.2 Trade regulation as a mean.................................................................................12

2.3 Other international environmental law as a mean ............................................13

3. Used EEE or WEEE? ..........................................................................................................15

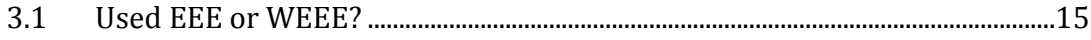

3.2 Definitions of the WEEE directive........................................................................15

3.3 Definitions of the waste directive........................................................................16

3.4 The interaction between the definitions of the WEEE directive and the waste directive ...............................................................................................17

3.5 Conclusion...................................................................................................................19

4. Basel Convention and EU Regulation on shipments of waste.....................................21

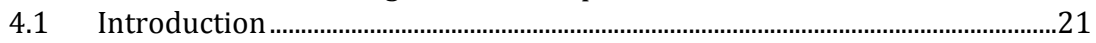

4.2 The Basel Convention...............................................................................................21

4.3 EU Regulation on shipments of waste.................................................................21

4.4 Conclusion................................................................................................................23

5. Import and export restrictions within the European Union .......................................25

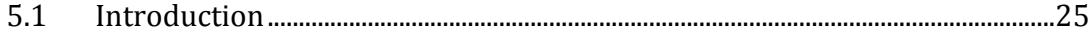

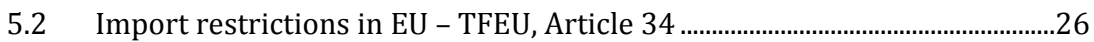

5.3 Export restrictions in the EU - TFEU, Article 35................................................33

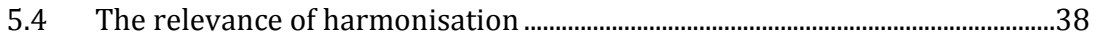

5.5 Case study - TFEU and the WEEE directive .........................................................39

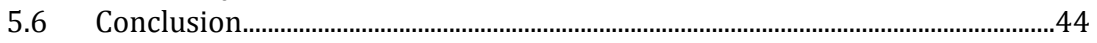

6. Export restrictions on export outside the European Union ........................................47

6.1 Introduction.....................................................................................................

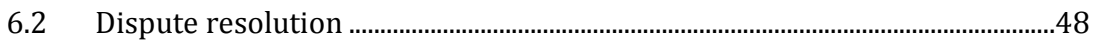

6.3 WTO Legality of a used EEE Trade Ban ...............................................................49

6.4 Case study - WTO and the WEEE-directive........................................................56

6.5 Conclusion...................................................................................................................5

7. Montreal Protocol on CFCs and EU Regulation on Substances that Deplete the Ozone Layer .................................................................................................59

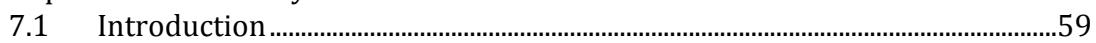

7.2 The Montreal Protocol ...........................................................................................59

7.3 EU regulation on substances that deplete the ozone layer ...............................60

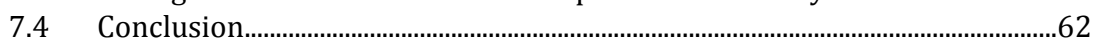


8. Stockholm Convention and EU regulation on persistent organic pollutants............63

8.1 Introduction ..................................................................................................................................63

8.2 The Stockholm Convention ..........................................................................................................63

8.3 EU regulation on persistent organic pollutants.................................................................64

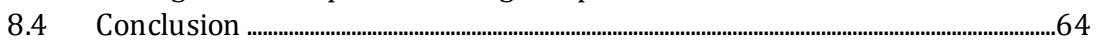

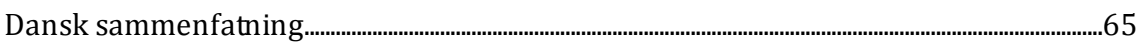

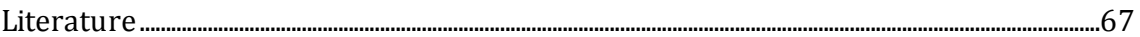

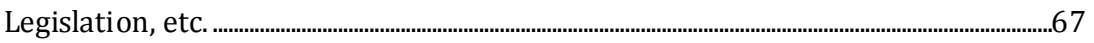

Cases from the European Court of Justice ................................................................................................67

Instructions and Reports........................................................................................................................68

Books ....................................................................................................................................69

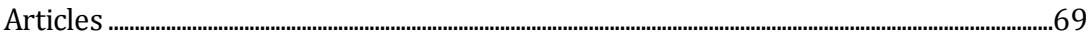




\section{Preface}

\section{Purpose}

Export of "used electric and electronic equipment" (used EEE) to primarily Asia and Africa that is of no or little use to the receivers is often considered export of "waste of electric and electronic equipment" (WEEE), as the result of an export often is that the used EEE never goes on the market and instead becomes subject to waste treatment of poor quality. ${ }^{1}$

The purpose of this report is to clarify the legal possibilities of restricting export of certain types of used EEE due to e.g. content of hazardous substances, energy consumption and/or limited market value. The aim of the project is to increase the knowledge about what can be done and what cannot be done in the current regulative set-up.

The results of the project will be used as input in the possible upcoming work of revising Annex VI in the EU Commission and the CENELEC standards currently under development concerning re-use of EEE/WEEE.

\section{Scope}

The scope of this report is a focused juridical analysis of the possibilities to impose a ban or other restrictions on export of used EEE.

Two tracks have been pursued in this analysis:

- When does used EEE become waste and subject to waste legislation?

- Can used EEE that is not considered waste be subject to restrictions in accordance with the EU rules concerning the internal market and the rules on trade barriers administered by the World Trade Organisation that regulate trade between countries worldwide. 
Also, as specified by the Nordic Council of Ministers, the following legal framework has been subject to evaluation:

- WEEE, RoHS and eco-design directives.

- Stockholm Convention and EU regulation on persistent organic pollutants.

- Montreal Protocol and EU regulation on substances that deplete the ozone layer.

- The Treaty of the Functioning of the European Union (TFEU).

- The Gatt Agreement.

As the EU has implemented the Basel Convention, the Stockholm Convention and the Montreal Protocol by EU regulations with direct legal effect, the evaluation has focused on the legal regimes of the EU regulations.

The focus of the evaluation of the specified legal framework has been to identify legal grounds as independent basis for restrictions on export on used EEE. Thus, the description of these legal regimes is kept brief.

\section{The waste track}

As regards waste, the report does not carve out the details of the waste legislation and the procedural rules of shipment of waste. It outlines the principles of the regulation.

The important question for the juridical analysis regarding waste legislation is when the used EEE can be considered waste. Thus, the analysis and the description of the results of the analysis focus on this question.

\section{The trade track}

Even though waste is also considered goods if a commercial incentive to trade can be established, trade of waste is not in focus in this report. If used EEE is actually considered WEEE, special harmonised rules apply.

It is in fact used EEE that is in focus on "the trade track" as an inspection, requirement of functionality or a ban on certain types of used EEE as a starting point will constitute a trade barrier for a regular product: An obstacle to the trade of a used electronic device. 


\section{Introduction}

It is estimated that approximately 50,000-100,000 tons of used EEE is exported out of the Nordic region every year. ${ }^{2}$ This amount consists of used EEE that is exported for re-use, but probably also large amounts of WEEE disguised as used. It is of high concern to find ways that can contribute to reduce the undesired shipment of disguised WEEE, because it creates waste and environmental problems in the countries receiving these shipments.

The purpose of this report is to conduct an analysis on whether it is possible to impose export restrictions on used EEE to avoid export of disguised WEEE to less developed countries.

There has been specified a number of environmental EU directives and regulations to be evaluated in order to identify if they can serve as the legal basis for setting restrictions on export. Also, some international conventions have been identified for the evaluation.

Besides this, the analysis concentrates on the legal framework of trade within the rules of the internal market in the EU and the legal concept of the WTO that regulates trade between countries worldwide. In general, any export restriction on used EEE must comply with the rules of trade, but some exemptions apply to this as described in chapters 5 and 6 .

The report basically has three focus areas:

- How can the waste legislation apply to used EEE?

- Can export restrictions on export of used EEE be adopted?

- Can international environmental rules serve as a basis for export restrictions of used EEE? 



\section{Main conclusions}

\subsection{Waste regulation as a mean}

The Basel Convention and the EU regulation on shipments of waste provide a strong regulatory regime in regards to restriction and prohibition of export of waste for recovery or disposal.

In general, the definition on waste must be applied on basis of a concrete assessment of the used EEE. Thus, EU Member States cannot adopt into their legislation a general rule determining that EEE and used EEE with certain features should be considered WEEE. If EU directives or regulations do not provide specific grounds, such general rules will violate the demand for concrete application of the definition of waste.

However, the WEEE Directive contains specific provisions determining when used EEE under suspicion as WEEE must be considered WEEE.

The fact that used EEE cannot be considered WEEE, unless it is decided on basis of a concrete assessment or in accordance with the rules of Annex VI of the WEEE Directive serve as a frame for the design of a possible export restriction on used EEE not suspected to be WEEE.

In other words, the analysis shows that rules on a possible export restriction on used EEE that may be adopted by the Nordic countries cannot deem used EEE as WEEE, if this is not based on a concrete assessment based on the definition on waste or Annex VI of the WEEE Directive. Thus, an export restriction on used EEE that provides for a general assumption that used EEE not suspected to be WEEE, must be considered WEEE, calls for changes of the Waste or the WEEE Directive. For example specific types of used EEE could be defined as WEEE in the directives or further development of the concept of Annex VI of the WEEE Directive could be pursued.

Accordingly, the current regulatory regime on waste cannot serve as basis for a possible export restriction on used EEE that aims to bypass the demand for a concrete assessment in accordance with the definition of waste in the waste directive. 


\subsection{Trade regulation as a mean}

This report seeks to clarify the legal possibilities of restricting export of certain types of EEE resulting from e.g. content of hazardous substances, energy consumption and/or limited market value. It is clear that the underlying assumption here is that some EEE which is in fact WEEE will end up in less developed third countries.

Used EEE is subject to different regulatory regimes depending on the route and destination of the goods.

Export to another EU country is not the appropriate gateway for such goods mainly because all EU Member States are required to implement the same regulatory framework, most notably the WEEE directive.

However, the exporter of the goods can use another EU country as a "transit country" or he might even find possible buyers for the goods in less privileged EU Member States before possibly continuing its journey outside the EU. Therefore it is necessary for the purpose of the report to examine whether there are any rules on export in EU law that prohibit a national measure in the exporting country supplying the obligations in the WEEE directive on shipments, or similarly if there are rules on import in EU law which will be infringed if the transit country instead enforces a trade barrier. Thus, both import and export restrictions in EU law are discussed in chapter 5 .

Regulation of used EEE exported with EU Member States as transit or destination countries which exceeds the requirements in the WEEE directive but does not conflict with it, must be conducted in accordance with the provisions on free movement of goods in the treaties of the European Union.

Generally, restrictions imposed by the country of origin on export of used EEE within the European Union can only be adopted within the legal framework of the WEEE Directive, if similar restrictions apply on trade with used EEE within this country of origin. This means that an export restriction on e.g. used CRTs must be supplemented with a restriction on trade with used CRTs within the country of origin.

As a starting point, restrictions that exceed the requirements stated in the WEEE directive will constitute a trade barrier. Under some circumstances, however, the restrictions can be justified if these aim at protecting the environment and are proportionate.

Regulation of EEE exported from the country of origin in the EU to non-EU Member States must be conducted in accordance with the rules of the WTO (World Trade Organization). 
In general, the WTO regime also prohibits restrictions on export imposed by the country of origin, if similar restrictions on trade do not apply within the country of origin.

However, in the WTO regime, restrictions justified in protection of the environment are exempted. Thus, export restrictions can be adopted, if they are justified in protection of the environment.

The export restriction justified in the protection of the environment is, however, only in accordance with the rules of the WTO regime, if it is designed and administered in a factually and foreseeable manner. This constitutes a challenge in regards to the design and administration of an export restriction.

It should be noted that the enforcement of the WTO legal regime is based on bilateral relations. Therefore, an export restriction that prohibits export of used EEE to e.g. a country in Africa would only be subject to a procedure, if that country brings it before the dispute resolution bodies of the WTO.

\subsection{Other international environmental law as a mean}

Some of the international environmental law contains specific rules on import and export of used EEE that may be useful in regards to restricting export of used EEE.

The Montreal Protocol and the EU Regulation on substances that deplete the ozone layer contain rules on both a ban and licensing of products containing CFCs. Export licence can only be provided by the EU Commission after application of a competent authority of an EU Member State. In general, export of used EEE containing CFCs seems very difficult.

The Stockholm Convention and EU Regulation on persistent organic pollutants do not contain an explicit ban or licensing regime in regards to export, including export of used EEE. The rules do, however, have a strong focus on avoiding any circulation, trade, etc., of any article containing POPs. Thus, the ban on production, placing on the market or use of articles applies to used EEE containing POPs. This will constitute an indirect ban on export of used EEE containing POPs.

The RoHS and eco-design directives do not independently contain any legal grounds for applying export restrictions on used EEE. 



\title{
3. Used EEE or WEEE?
}

\subsection{Used EEE or WEEE?}

An important distinction is to be made between used EEE and WEEE. This distinction is important because the rules applying to waste provide a much stronger basis for authorities to restrict and control the movement of waste between states. In this chapter, the application of the definition of waste and WEEE is evaluated in regards to used EEE. The purpose of the chapter is to describe when the stricter regulatory regime applying to export of WEEE can be applied to used EEE.

As the focus of this report lies on the Nordic countries, the central regulatory framework for WEEE is the WEEE directive. ${ }^{3}$

\subsection{Definitions of the WEEE directive}

Electric and electronic equipment is defined in Art. 3, section 1, litra a, of the WEEE directive:

\footnotetext{
"electrical and electronic equipment" or "EEE" means equipment which is dependent on electric currents or electromagnetic fields in order to work properly and equipment for the generation, transfer and measurement of such currents and fields and designed for use with a voltage rating not exceeding 1000 volts for alternating current and 1500 volts for direct current.
}

Waste of electrical and electronic equipment is defined in Art. 3, section 1, litra e, of the WEEE directive:

\begin{abstract}
"waste electrical and electronic equipment" or "WEEE" means electrical or electronic equipment which is waste within the meaning of Article 3(1) of Directive 2008/98/EC, including all components, sub-assemblies and consumables which are part of the product at the time of discarding.
\end{abstract}

Art. 3, section 2, states that a number of definitions from the Waste directive apply within the scope of the WEEE directive. 4 This applies as

${ }^{3}$ Directive 2012/19/EU of the European Parliament and of the Council of 4 July 2012 on waste electrical and electronic equipment (WEEE). 
regards the definitions of "hazardous waste", "collection", "separate collection", "prevention", "re-use", "treatment", "recovery", "preparing for re-use", "recycling" and "disposal".

Used EEE is not defined.

\subsection{Definitions of the waste directive}

The waste directive contains the central and decisive definition of waste, which is integrated as a part of the definition of waste.

According to Art. 3, 1), waste is defined as follows:

"waste" means any substance or object which the holder discards or intends or is required to discard.

\subsubsection{Understanding the content of the definition of waste}

The important part of the definition of waste is the key term "discard" combined with the three alternatives in the actions, intentions or obligations of the holder. ${ }^{5}$

The holder may in these three ways turn substances or objects into waste. A lot of everyday situations do not conflict with the definition e.g. an item thrown into a recycle bin. However, the dynamic of the definition often results in uncertainty when applying the definition. ${ }^{6}$

As mentioned by the European Commission in its interpretation guide on the waste directive, the European Court of Justice has provided a few non-exhaustive clarifications regarding the concept of discarding: 7

- Discard applies to both recovery and disposal of waste. However, it should be noted that this does not mean that any substance which undergoes a recovery/disposal operation as listed in the Annexes of the waste directive is waste per se, but it might be regarded as evidence for being waste. ${ }^{8}$

\footnotetext{
4 Directive 2008/98/EU of the European Parliament and the Council of 19 November 2008 on waste and repealing certain directives.

${ }^{5}$ Joined Cases C-418/97 and C-419/97 (ARCO), para 36.

${ }^{6}$ European Commission, "Guidance on the interpretation of key provisions of Directive 2008/98/EC on waste", p. 10.

${ }^{7}$ European Commission, "Guidance on the interpretation of key provisions of Directive 2008/98/EC on waste", p. 10 et seqq.

${ }^{8}$ Joined cases C-418/97 and C-419/97 ARCO, para 51, Case C-9/00 Palin Grant Oy, para 27.
} 
- Discard can involve a positive, neutral, or negative commercial value. No distinction is made based on whether the substance/object is marketable or not. ${ }^{9}$

- Discard can be intentional/deliberate on the part of the holder or unintentional/involuntary/accidental or can even occur with or without the knowledge of the holder. ${ }^{10}$

- The storage location of a material does not influence whether it is waste or not. ${ }^{11}$

The European Court of Justice (ECJ) has concluded that the definition must apply on the basis of a concrete assessment of all circumstances of relevance in each situation, and the application of the definition is subject to a wide interpretation in light of the purpose of the waste directive. ${ }^{12}$ On this basis, EU Member States cannot adopt into their legislation a general rule determining that EEE and used EEE with certain features should be considered WEEE. It violates the demand for concrete application of the definition of waste.

However, as elaborated below, the WEEE directive contains such basis as regards used EEE under suspicion of being WEEE.

\subsection{The interaction between the definitions of the WEEE directive and the waste directive}

According to the definition of WEEE, the decision on classification of used EEE as waste entirely depends on the definition of waste as set out in the waste directive.

If used EEE is considered waste under the definition of the waste directive, it is considered WEEE.

Thus, the criteria set out in Art. 3 , section 1 in the waste directive as developed by the ECJ are decisive in the discussion on whether EEE and used EEE is considered WEEE.

\footnotetext{
${ }^{9}$ Joined cases C-206/88 and C-207/88 Vessoso and Zanetti, para 9.

${ }^{10}$ Case C-252/07 Thames Water, para 28.

${ }^{11}$ Case $\mathrm{C}-1 / 03$ van der Walle, paras 46 et seqq.

${ }^{12}$ Case C-194/05, para 41 and joined Cases C-418/97 and C-419/97 (ARCO), para 37-39.
} 


\subsubsection{General criteria for considering used EEE as WEEE}

The supervising authority will usually have the competence to decide whether used EEE should be considered WEEE.

This is based on a concrete assessment based on the definition of waste and the criteria set out by the European Court of Justice mentioned above. Used EEE becomes WEEE if its holder discards it, or intends or is required to discard it. To make this judgement it is necessary to examine the history of an item on a case-by-case basis.

Depending on the situation at hand, the supervising authority can, however, also rely on specific criteria of relevance as regards assessment of used EEE as WEEE.

In the end these criteria serve as indicators directing a decision on, whether the used EEE in the concrete circumstances can be considered WEEE.

The revised Correspondents' Guidelines no. 1 contain several criteria to be used by the Member States when deciding on classification of units as used EEE or WEEE. ${ }^{13,} 14$

According to the Correspondents' Guidelines no. 1, used EEE would normally be considered WEEE if the following criteria are met:

- The product is not complete - essential parts are missing.

- It shows physical damage that impairs its functionality or safety, as defined in relevant standards.

- The packaging for protecting it from damage during transport and loading and unloading operations is insufficient.

- The appearance is generally worn or damaged, thus reducing the marketability of the item(s).

- The item has among its constituent part(s) anything that is required to be discarded or is prohibited under community or national legislation (e.g. asbestos, PCBs, CFCs).

- The used EEE is destined for disposal or recycling instead of re-use.

- There is no regular market for the used EEE.

- It is old or out-dated used EEE destined for cannibalisation (to gain spare parts).

\footnotetext{
${ }^{13} \mathrm{http}: / /$ ec.europa.eu/environment/w aste/ship ments/pdf/correspondents_guidelines_en.pdf ${ }^{14}$ The Correspondents' Guidelines are published by the European Commission and have been agreed upon by the waste shipment correspondents of the EU Member States. They represent their common understanding of how the Regulation on shipments of waste should be interpreted. They are not legally binding. The binding interpretation of Community law is the exclusive competence of the European Court of Justice.
} 
According to the Revised Correspondents' Guidelines no. 1, used EEE would not normally be considered WEEE:

- where the criteria mentioned under 5.3.1 are met and if it is fully functioning and is not destined for any of the operations listed in Annex II of the waste directive (recovery or disposal operations) and is directly re-used for the purpose for which it was originally intended or presented for sale or exported for the purpose of being put back to direct re-use or sold to end consumers for such re-use

- where the two last criteria mentioned under 5.3.1 are met and if it is sent back as defective batches for repair to the producer or repair centres (e. g. under warranty) with the intention of re-use.

As stated above, it is not in compliance with the practice of the ECJ if a general rule determining under which circumstances used EEE is considered WEEE is adopted in national law. This also applies if a Member State decides on a fixed practice on the basis of the above-listed criteria. The definition of waste applies directly in all EU Member States and must be applied on a case-by-case basis.

\subsubsection{Used EEE as WEEE - WEEE directive Annex VI}

Deviation from the general rule of application of a concrete assessment when deciding the definition of waste requires a specific legal base.

Such legal basis is provided in Art. 23, section 2, combined with Annex VI in the WEEE directive.

Basically, Annex VI of the WEEE directive provides legal grounds for general rules determining when used EEE can be considered WEEE, if the used EEE is suspected to be WEEE. If the requirements to documentation, functionality, packaging, etc. are not met, Annex VI, 5) provides the legal basis for consideringused EEE under suspicion as WEEE.

The requirements for documentation, test, etc. are described under 5.3.5.

\subsection{Conclusion}

The distinction between used EEE and WEEE is of great importance, as the Regulation on shipments of waste contains strong legal instruments as regards restricting export of used EEE, if it should be considered WEEE. 
The definition of waste is the decisive factor in applying the Regulation on shipments of waste to used EEE. The definition is, however, difficult to apply, where the holder of used EEE claims that the used EEE is not WEEE.

The ECJ has determined that the definition of waste must be applied on the grounds of a concrete assessment. Thus, a general rule or fixed practice cannot be adopted by the EU Member States as regards determination of when used EEE is considered WEEE.

The EU Member States must apply the definition on a case-by-case basis, but they may use the variety of criteria of relevance as basis for the decision to consider used EEE as WEEE. Applying the criteria correctly under good judgement gives the Member States a good platform as regards classifying used EEE as WEEE on a case-by-case basis.

Shipment of used EEE under suspicion as WEEE is subject to specific requirements for documentation and may, if the requirements for documentation are not met, be subject to the procedures applying to WEEE. In such cases, the used EEE is considered WEEE that can only be shipped in accordance with the EU Regulation on shipments of waste. If the shipment is already in progress and the requirements of the EU Regulation on shipments of waste are not complied with, the authorities can demand that the shipment be returned in accordance with the provisions 24 and 25 of the EU Regulation on shipments of waste

Export restrictions can be applied in accordance with the Regulation on shipments of waste, when used EEE is considered WEEE. The restrictions may, however, not be based on general provisions determining when used EEE is considered WEEE, unless such provisions are in accordance with the terms in the WEEE directive's Art. 23, section 2 and Annex VI. 


\section{Basel Convention and EU Regulation on shipments of waste}

\subsection{Introduction}

Import and export of waste, including WEEE, are subject to detailed regulation and involve many possibilities as regards applying restrictions.

The focus of this report is export restrictions on EEE and used EEE. Thus, this report will only give a brief introduction to the main possibilities as regards restrictions under waste legislation to illustrate the importance of the distinction between used EEE and WEEE.

The introduction also underlines the importance of the correct application of the definition of waste as set out in the waste directive and the suspicion-rule in the WEEE directive.

\subsection{The Basel Convention}

The text of the Basel Convention on the Control of Transboundary Movements of Hazardous Wastes and their Disposal was adopted on 22 March 1989. Shipment of waste is regulated in the EU's Regulation on shipment of waste. ${ }^{15}$ The regulation implements the Basel Convention.

\subsection{EU Regulation on shipments of waste}

The regulation implements the procedures and control schemes for shipments of waste of the Basel Convention.

The complexity of the procedure and the possibilities to exercise control depend on the origin, destination, route, type and treatment of the waste. The procedure for shipment of waste is divided into two

${ }^{15}$ Regulation (EC) no. 1013/2006 of the European Parliament and the Council of 14 June 2006 on shipments of waste as amended. 
categories. Waste can either be shipped after the procedure for greenlisted waste (free movement) or it has to be notified to the national competent authority.

The regulation applies to shipment of waste between EU Member States, import from or export to non-EU Member States, and transit through EU Member States on its way to non-EU Member States. 16

\subsubsection{Used EEE under suspicion as WEEE}

According to Article 23, section 2, of the WEEE directive, EU Member States must ensure that shipment of used EEE suspected to be WEEE is carried out in accordance with the minimum requirements in Annex VI and must monitor such shipments accordingly.

Annex VI and the Revised Correspondents' Guidelines no. 1 declare that certain documentation may be requested when a holder of used EEE that might be considered WEEE claims that he intends to ship or is shipping used EEE and not WEEE.

Annex VI requires that the following should be provided to back up this claim towards an authority at its request:

- A copy of the invoice and contract relating to the sale and/or transfer of ownership of the used EEE stating that the equipment is destined for direct re-use and that it is fully functional.

- Evidence of evaluation or testing in the form of a copy of the records (certificate of testing, proof of functionality) on every item within the consignment and a protocol containing all record information according to point 3.

- A declaration made by the holder arranging the transport of the used EEE that none of the material or equipment within the consignment is waste as defined by Article 3(1) of Directive 2008/98/EC.

- Appropriate protection against damage during transportation, loading and unloading, in particular by way of sufficient packaging and appropriate stacking of the load.

In some cases, the above-mentioned requirements for documentation do not apply, cf. Annex VI, 2.

${ }^{16}$ Exemptions apply to e.g. certain types of waste or shipment, but they are generally not of relevance to shipment of WEEE. 
Annex VI, 3) also sets out requirements considered suitable to confirm that the used EEE is not WEEE. The requirements are divided into two tiers; testing and records.

Functionality must be tested and the presence of hazardous substances must be assessed. The tests to be conducted depend on the type of used EEE. For most used EEE, a functionality test of the key functions is sufficient. The results of assessment and testing must be recorded.

The record showing specific information, including results of functionality test and evaluation of hazardous substances, must be attached to the used EEE itself or to the packaging so it is readable without unpackaging of the used EEE.

According to Annex VI, 4) a shipment of used EEE must also be accompanied by a relevant transport document, e.g. CMR or waybill, and a declaration by the liable person on its responsibility.

If it is proved that the used EEE is not WEEE or sufficient documentation is not provided, EU Member States will consider the used EEE as WEEE, cf. Annex VI, 5). Thus, the shipment will be considered an illegal shipment of WEEE since it has not been notified as a shipment of waste.

\subsection{Conclusion}

If used EEE is considered WEEE, the EU Regulation on shipments of waste provides a wide range of opportunities to object to shipment of WEEE.

Shipment of WEEE for disposal can be made subject to a general ban.

Unless green-listed, shipment of WEEE for recovery is subject to notification and the Member States have the right to demand information about the shipment that will allow the authorities to stop the export of WEEE for recovery for other EU Member States as well as non-EU Member States if the purpose of the shipment is really not recovery.

Shipments of used EEE under suspicion as WEEE are subject to specific requirements for documentation and may, if the requirements for documentation are not met, be subject to the procedures applying to WEEE.

The EU Regulation on shipments of waste does, however, not provide any basis for import or export restrictions for used EEE in general. Only if used EEE is suspected to be WEEE, the rules of the EU Regulation on shipments of waste can be applied. This must be decided on a caseby-case basis. 



\section{Import and export restrictions within the European Union}

\subsection{Introduction}

In the following chapter the rules on import and export in EU will be examined in order to analyse if possibilities to restrict import and/or export of used EEE to either other EU Member States or countries outside the EU exist. Also possibilities contained in the WEEE directive will be analysed.

The rules on import and export between EU Member States are laid down in the Treaty on the Functioning of the European Union (TFEU). The rule on import is regulated in Article 34, whereas the rule on export is regulated in Article 35. The exceptions to both these provisions are found in Article 36. The articles read as follows:

Art. 34:

Quantitative restrictions on imports and all measures having equivalent effect shall be prohibited between Member States.

Art. 35:

Quantitative restrictions on exports, and all measures having equivalent effect, shall be prohibited between Member States.

Art. 36:

The provisions of Articles 34 and 35 shall not preclude prohibitions or restrictions on imports, exports or goods in transit justified on grounds of public morality, public policy or public security; the protection of health and life of humans, animals or plants; the protection of national treaures possessing artistic, historic or archaeological value; or the protection of industrial and commercial property. Such prohibitions or restrictions shall not, however, constitute a means of arbitrary discrimination or a disguised restriction on trade between Member States. 


\subsection{Import restrictions in EU - TFEU, Article 34}

In the following it will be discussed how Article 34 is interpreted by the European Court of Justice (ECJ) and thereby it will also be established what room is left for the Member States to set national import restrictions.

\subsubsection{What is an import restriction?}

As stated above, Article 34 results in "quantitative restrictions" and "measures having equivalent effect" being prohibited. In the following, these terms will be explained.

Quantitative restrictions (limitations on imports measured in units or weight) on imports fall under the scope of Article 34 since this directly follows from that provision. In the Guide on import restrictions (see annex 1) it appears under ex. 9 that Indonesia maintains a ban on import of second-hand microwave ovens. This is an example of a pure quantitative restriction as the import is set to 0 . The ban would clearly fall within the frame of Article 34, if Indonesia were an EU Member State.

By contrast, it is not clear what is meant by measures having equivalent effect. The ECJ has developed this throughout the past 40 years of case law. With Article 34's scant description of the ban, the ECJ had a fundamental choice to limit the scope of the ban to cover only national measures that discriminated against foreign goods or to embrace all national measures that impede or restrict trade. In the development in case law from the Dassonville case to the Cassis de Dijon case,17 18 the ECJ showed that it eventually chose the latter solution to embrace all national measures. Dassonville concerned a Belgium rule preventing the sale of products such as Scotch whisky without a certificate of authenticity. The ECJ ruled that measures having an equivalent effect were to be understood as:

[a]ll trading rules enacted by Member States which are capable of hindering, directly or indirectly, actually or potentially, intra-Community trade [...]

(para.5).

This made the measure in the Dassonville case covered by the prohibition in Article 34. The ruling was a milestone in ECJ practice, since the

\footnotetext{
${ }^{17}$ Case 8/74, Dassonville.

${ }^{18}$ Case $120 / 78$, Rewe-Zentral.
} 
given definition of measures having an equivalent effect, particularly with reference to "indirectly" and "potentially", was so broad that, in principle, any national measure should then be covered by the prohibition in Article 34. Moreover, the ECJ later ruled that there is no lower threshold, meaning that even if no (serious) impact on imports caused by the measure was documented, it was still to be classified as an obstacle according to Article 34 .

However, since the Dassonville case concerned a discriminatory measure, it was not clear whether the ECJ would also apply Article 34 in situations where domestic products were treated similarly to imported products. This was the case in Cassis de Dijon. The case concerned a German measure stipulating that products sold as fruit liqueur had to contain at least $25 \%$ alcohol by volume. The French liqueur contained just $15 \%$ and could therefore not be sold as fruit liquer in Germany.

In the Cassis de Dijon case, the ECJ apparently introduced, without rejecting the Dassonville doctrine, another barrier concept. In this case the ECJ held that:

[T] here is therefore no valid reason why, provided that they have been lawfully produced and marketed in one of the Member States, alcoholic beverages should not be introduced into any other Member State; the sale of such products may not be subject to a legal prohibition on the marketing of beverages with an alcohol content lower than the limit set by the national rules.

(para.14).

With this case, the ECJ first and foremost showed that Article 34 would embrace all national measures impeding or restricting trade - discriminatory or not - since the measure in Cassis de Dijon treated domestic and foreign liquor in the same way. Moreover, the cited paragraph 14 shows that ECJ introduced a principle of mutual recognition, whereby the essential factor in assessing whether there is a trade barrier is whether a product lawfully marketed in one Member State is now prevented from being marketed in another Member State.

Now, this was a remarkable change. Historically the idea behind the free movement idea was to eliminate the Member State's deliberate intention to protect domestic production by imposing explicit import restrictions. Now, the ban was so broad that just the fact that a producer needed to change the production method according to the country exported to would constitute an import restriction. This is a very wide measurement of obstacles to trade, suitable for establishment of a more or less complete common market with, eventually, common trade laws. 


\subsubsection{Can an import restriction ever be accepted?}

The rules on trade recognise that there sometimes will be an acceptable need for imposing an import (or export) restriction. Again, the overall idea is to make sure that a Member State does not take the benefits of an open market to export its own products, but at the same time closes its own market for imports. Measures enacted in order to pursue other aims than disturbing the market may, however, be valid. E.g. as long as the rules on the use of artificial colour in food are not harmonised, the Member States will be allowed to impose different protection levels when it comes to public health. In other words: A ban on the use of artificial colour may constitute an import restriction if the country of origin does not have a similar ban, but this restriction may be justified if there is an acceptable reason for the restriction. Historically, the only acceptable reasons were to be found in the exhaustive list in Article 36.

However, the above mentioned case, Cassis de Dijon, is particularly known for its paragraph 8, introducing the "doctrine of the principle of mandatory requirements" which was seen as an inevitable consequence of the fact that the ECJ chose the wide barrier concept. Paragraph 8 reads:

[...] Obstacles to movement within the Community resulting from disparities between the national laws relating to the marketing of the products in question must be accepted in so far as those provisions may be recognised as being necessary in order to satisfy mandatory requirements relating in particular to the effectiveness of fiscal supervision, the protection of public health, the fairness of commercial transactions and the defence of the consumer.

The consequence of the fact that all national measures - discriminatory or not - should be considered as covered by Article 34, was that the limited and exhaustive exceptions in Article 36 were not sufficient. It was in other words generally not considered satisfactory if all these national measures could only be legitimised under the exhaustive exceptions listed in Article 36, which is an article that is to be interpreted restrictively, until national legislation could pass the Article 34 test. Hence, in Cassis de Dijon, the ECJ expanded the exception area and held that:

[...] Obstacles to movement within the Community resulting from disparities between the national laws relating to the marketing of the products in question must be accepted in so far as those provisions may be recognised as being necessary in order to satisfy mandatory requirements relating in particular to the effectiveness of fiscal supervision, the protection of public health, the fairness of commercial transactions and the defence of the consumer. 
The Cassis de Dijon doctrine therefore entails that Member States have a wider access to justify exceptions to the strict prohibition in Article 34. Exceptions not mentioned in Article 36 may hereafter be justified, if the restriction on trade is considered legitimate and is not directly discriminatory but solely indirectly discriminatory.

Member States were therefore not constrained by having to prove that the legislation in question was proportionate and pursued without discrimination the specific narrow accounts in Article 36, but could now, in principle, also rely on any overriding reason to the extent that national legislation was not discriminatory, since the use of the words "in particular" in paragraph 8 shows that the list of creditable accounts given in this paragraph was not intended to be exhaustive.

In principle, the system is (at least at this point) therefore quite clear: The principle of mutual recognition in conjunction with the Dassonville doctrine is used to determine whether a measure falls under Article 34. Then the second part of the test is to determine whether the measure is directly discriminatory. If this is the case, only the escape clause provided by the Treaty in Article 36 can except the national provision from the prohibition in Article 34. This means that only the protection of public health, safety, etc. may justify a restriction. If the measure is not directly discriminatory, the non-exhaustive list of accounts in Cassis de Dijon is also invoked, meaning that in principle any reason may justify an import restriction except of course from a sole intention to protect own products.

If a compelling reason can justify the measure either according to Article 36 or the Cassis de Dijon doctrine, the last step is to examine whether the restriction in question is in fact a proportionate way to pursue the invoked compelling reason. This test is usually described as a two-tier test:

1. Is the measure appropriate for the purpose of ensuring the claimed goal? if yes.

2. Is the measure necessary to attain the legitimate objective being pursued?

In recent years the ECJ has developed the system even further with the result that a lot of national measures are no longer in the danger zone. Now national rules on opening hours, advertising, distribution and sale at retail level (not at import level) will no longer fall under the scope of Article 34 if the measure applies: 
to all relevant traders operating within the national territory and so long as they affect in the same manner, in law and in fact. ${ }^{19}$

This is known as the (socalled) "Keck doctrine".

\subsubsection{Expanding the area of import restrictions}

In two 2009-cases the ECJ seems to have developed a specific market access rule, apparently without assessing the Keck doctrine. In the first case, the Commission v the Italian Republic, ${ }^{20}$ concerning a total ban on the use of specially produced trailers for motorcycles, mopeds, motor tricycles and quadricycles, the ECJ not only explicitly ruled that regulations that impede market access are covered by Article 34, apparently regardless of the type of legislation and whether it is discriminatory or not, the ECJ also ruled that a total use ban should be regarded as such a restriction on access to markets. In the second case, Åklagaren v Percy Mickelsson and Joakim Roos, ${ }^{21}$ concerning a prohibition on the use of personal watercraft on waters other than general navigable waterways, the ECJ further developed the rule so that limitations in use of a product are also governed by Article 34. This means that measures that impede access to a market are prohibited unless the Member State has compelling reasons for the measure.

\subsubsection{How to perform the import restriction test}

Some scholars argue that the ECJ may not be operating with what one could call "three approaches". ${ }^{22}$ This is to explain the not always clear outcome of cases from the ECJ. The first approach is the most conservative, and it suggests that any discriminatory measure, whether direct or indirect, under the scope of Article 34 must be justified according to Article 36. If it does not pass this test, the measure will be considered contrary to the Treaty. The second approach suggests that quantitative restrictions and directly discriminatory measures must be justified under Article 36, while indirectly discriminatory and nondiscriminatory measures may be accepted both according to Article 36 and any compelling reason according to the cassis de Dijon doctrine. The third approach is the most liberal approach and the most "Member

\footnotetext{
${ }^{19}$ Joined cases C-267/91 and C-268/91, Keck and Mithouard.

${ }^{20}$ Case C-110/05, Commission of the European Communities v the Italian Republic.

${ }^{21}$ Case C-142/05, Åklagaren v Percy Mickelsson and Joakim Roos.

${ }^{22}$ See Ulla Nergaard and Ruth Nielsen, Eu Ret, 6. rev. Udgave, Thomson, 2010, p. $312 \mathrm{ff}$.
} 
State friendly" approach, which suggests that both Article 36 and any compelling reason under Cassis de Dijon may justify any measure.

It is true that some decisions can be rather difficult to explain according to just one approach; however there is still reasonable agreement between scholars that in any case within the framework of obstacles to the movement of goods, the second approach is still dominating. The second approach will therefore be used in the following analysis of environmental reasons for establishing trade restrictions. ${ }^{23}$

\subsubsection{Import restrictions motivated by environmental concerns}

In terms of environmentally motivated national restrictions it should be observed that Article 36 does not mention the environment in a broad sense as a legitimate ground of justification for a national obstacle to imports.

This means that quantitative import restrictions and directly discriminatory measures cannot be justified with reference to the protection of the environment, as directly discriminatory obstacles can only be accepted if the underlying reason for the measure is mentioned in Article 36.24

Indirectly discriminatory measures and non-discriminatory measures can be accepted with reference to reasons both mentioned in Article 36 and according to the Cassis de Dijon doctrine and its nonexhaustive list of compelling reasons, including the environment. A national measure that only concerns marketing and distribution etc. at retail level and which applies to all relevant traders operating within the national territory and affects them in the same manner in law and in fact, will not even fall under the scope of Article 34 any longer and must therefore be accepted. Finally, a national measure which only concerns

\footnotetext{
${ }^{23}$ See Ulla Nergaard and Ruth Nielsen, Eu Ret, 6. rev. edition, Thomson, 2010, p. 384.

${ }^{24}$ Some argue that C-2/90 the Commission v Belgium is an example of the opposite: An environmental aim can justify a directly discriminatory measure and thus is an example of the use of the third approach described above. The case concerned a prohibition in Wallonia, Belgium, stating that it was not allowed to store, tip or dump waste in Wallonia originating in another Member State. ECJ accepted this prohibition for environmental reasons. What at first hand seemed like a directly discriminatory import restriction (only concerning "foreign" waste) was therefore justified for environmental reasons. However, in para. 36 of this case the ECJ states: "It follows that having regard to the differences between waste produced in different places and to the connection of the waste with its place of production, the contested measures cannot be regarded as discriminatory." The reasoning might seem awkward but nevertheless the court considers the case to concerned a not directly discriminatory measure, which - as said - can be justified under the Cassis de Dijon doctrine. Case C-379/98, PreussenElektra AG concerning af national requirement for private electricity supply undertakings to purchase electricity produced in their area of supply from renewable energy sources is more difficult to fit under the 2. approach.
} 
the use of the product but not its production, layout etc. will not be considered an obstacle if it does not impede access to the market according to caselaw from the ECJ.

Consequently a national measure stating that e.g. hazardous waste may not be imported cannot be accepted for environmental reasons. The measure is a quantitative restriction and per se directly discriminatory and can therefore be accepted only according to Article 36 where the environment is not mentioned. Any measure that dictates that hazardous waste should be subject to an inspection, must be labelled or should be packed in a certain way etc. will be a non-discriminatory measure as it applies to all hazardous waste whether domestic or foreign. Therefore it can be justified according to Cassis de Dijon and for environmental reasons, if the measure is proportionate to fulfil the aim of protection of the environment.

If the measure concerns where hazardous waste may be sold at retail or how selling may be advertised etc., it will not be contrary to Article 34 (at all) according to the Keck doctrine. Now, finally, if the national measure instead concerns the use of hazardous waste, the measure will also fall outside the scope of Article 34, as long as the measure does not impede access to the domestic market. The latter will be the case if national legislation e.g. states that hazardous waste may only be used by specific entities etc.

\subsubsection{Conclusion}

For the purpose of this report it may be concluded from the above that environmental motivated national measures with an impact on imports can normally only be in accordance with the Treaty if they

- only concern the marketing and distribution etc. at retail level and apply to all relevant traders operating within the national territory and affect them in the same manner, in law and in fact

- only concern the use of the product but not its production, layout etc. and do not impede access to the market

- are not directly discriminatory and the national measure can pass the test on proportionality. 


\subsection{Export restrictions in the EU - TFEU, Article 35}

In the following it will be discussed how TFEU, Article 35 is interpreted by the ECJ and thereby it will be established what the possibilities are for the Member States to set national export restrictions.

\subsubsection{What is an export restriction?}

TFEU Article 35 provides:

Quantitative restrictions on exports, and all measures having equivalent effect, shall be prohibited between Member States.

Even though the provision has almost the exact same wording as Article 34 (where the ECJ have chosen to embrace all national measures that impede or restrict trade (the first approach), see section 6.2.4), the ECJ has chosen the second solution approach in regards to Article 35. This means that the ECJ has limited the scope of the ban to cover only national measures that directly discriminate against exports, although it has presented a broad concept of discrimination, see below concerning Case $15 / 79$, Groenveld.

This means that normally Article 35 is only violated if it is proven that the obstacle to export of a product is only invoked because the product is exported, while the same product may be sold under no restrictions witin the country of origin. It may for instance benefit national production to have restrictions on export of valuable raw materials.

There is no doubt that Article 35 has given rise to much less case law than Article 34 on imports. The core of the ban in Article 35 is to prohibit that the domestic production and market are given an advantage over the production or the trade in other Member States. Case 15/79, Groenveld concerned a measure prohibiting sausage makers from having in stock or processing horse meat, thereby creating an impediement for export. In paragraph 7 ECJ stated:

\footnotetext{
That provision concerns national measures which have as their specific object or effect the restriction of patterns of exports and thereby the establishment of a difference in treatment between the domestic trade of a Member State and its export trade in such a way as to provide a particular advantage for national production or for the domestic market of the State in question at the expense of the production or of the trade of other Member States. This is not so in the case of a prohibition like that in question which is applied objectively to the production of goods of a certain kind without drawing a distinction
} 
depending on whether such goods are intended for the national market or for export. (Italic here).

The underlining shows what probably most commonly is the case regarding a domestic obstacle to one's trade: That something is equally prohibited on the domestic market, and in that case the export restriction is not contrary to Article 35. Thus, in that case the exporter cannot get rid of the obstacle according to Article 35.

Thus, while Article 34 can be violated even if the import restriction in the national legislation has an equivalent obstacle for domestic sale, Article 35 can only be violated if no equivalent obstacle exists on the domestic market compared with the export of the product.

\subsubsection{Can an export restriction ever be accepted?}

In a Dutch case a company was prohibited by the Dutch authorities from exporting waste oil filters and similar waste to Germany according to this limited possibility for export in Dutch law: 25

Export is permitted if a superior processing technique exists abroad or if there is insufficient capacity for processing a given type of waste in the Netherlands, unless that export makes it impossible to carry out disposal of an at least equivalent level in the Netherlands. In that case, the waste shall be stockpiled pending disposal.

In other words: The waste in question could only be exported if it was treated environmentally friendlier in another Member State. During the administrative complaint procedure the premises in Germany were inspected by the Dutch authorities who reached the conclusion that the processing performed by the German importer was not of a higher quality than that performed by the Netherlands' waste processing and management undertaking, and the export was not permitted.

In this case the ECJ stated that it was clear that the object and effect of such a provision was to restrict exports and to provide a particular advantage for national production. Thus, Article 35 was relevant. The ECJ found that the Dutch provision was not justified; neither by an imperative measure relating to protection of the environment; nor by one of the derogations provided by Article 36 of the Treaty, but was more motivated by economic reasons, which can never justify an obstacle

${ }^{25}$ Case C-203/96, Chemische Afvalstoffen Dusseldorp. 
contrary to the Treaty. ${ }^{26}$ The case concerned waste for recovery and not waste for disposal as in $\mathrm{C}-2 / 90$ the Commission v Belgium. It is clear that both the European legislative framework and EU case law favours waste for recovery rather than waste for disposal when it comes to free movement. ${ }^{27}$

On its surface the above case is not surprising in itself. However, in paragraph 45 , the Netherlands claims that the provision is justified under the derogation provided by Article 36 of the Treaty concerning the protection of the health and life of humans. The ECJ rejected that statement but marked in paragraph 46 :

Such a justification would be relevant if the processing of oil filters in other Member States and their shipment over a greater distance as a result of their being exported posed a threat to the health and life of humans.

This seems contrary to Article 34 where the normal approach from international law is generally understood to apply, meaning that a Member State cannot protect interests on other Member States' territories. ${ }^{28}$

Another reason why the case is interesting is the fact that the decision seems open for application of the Cassis de Dijon doctrine, also when it comes to export restrictions. It should be remembered from the previous section about import restrictions that this doctrine means that national provisions contrary to Article 35 may be exempt from the prohibition not only according to the exhaustive list of acceptable reasons in Article 36, but also - if the measure is not directly discriminatory - according to a non-exhaustive list of reasons of in principle any other compelling reason.

As mentioned Article 35 only deals with discriminatory measures, and the Cassis de Dijon doctrine is generally understood as only relevant if the national provision is indirectly discriminatory. If directly discriminatory, only Article 36 applies. If not discriminatory at all, the provision does not fall under the scope of Article 35.

Does this mean that the ECJ now accepts any compelling reason as acceptable justification of a directly discriminatory measure? Some authors suggest exactly that: That the case C-203/96 may have been seen as a more far-reaching change of the application of Cassis de Dijon: Perhaps it

\footnotetext{
26 E.g. C-456/10, ANETT.

${ }^{27}$ See e.g. Tine Sommer, Juristen nr. 10 1998, side 379ff.

${ }^{28} \mathrm{EU}$, Danmark og miljøreglerne, http://mst.dk/service/publikationer/publikationsarkiv/2000/feb/eudanmark-og-miljoereglerne/
} 
means that now Cassis de Dijon - and therefore the environment in a broader sense - may be used to justify purely discriminatory measures?

That would obviously mean a lot for the aim of the investigation in this report, because this would mean that it would actually be possible to impose an export restriction on used EEE, even though this would be a diretly discriminatory measure because the sale of used EEE remains allowed on the domestic market. Why? Because the Member State can claim that the restriction is necessary in order to protect the environment. This aim is not a compelling reason in Article 36, which is usually considered the only exemption to a directly discriminatory measure, but it is indeed a compelling reason according to the Cassis de Dijon doctrine.

However, most authors suggest that the ECJ has not left the baseline: Article 36 is (still) the only provision to justify directly discriminatory measures. Perhaps there is an exception in the area of environment and even more narrow - the area of trade in waste, also with reference to C$2 / 90$ the Commission v Belgium (the Wallonie Waste case). However, this seems irrelevant for the purpose of this report which is to look for possibilities to restrict the trade of used EEE, which is not waste. That would be an obstacle to trade e.g. a used TV set - not an obstacle to trade waste. This obstacle can in any case only be justified according to Article 36 .

Again, if a compelleing reason is found, the proportionality test must be passed:

1) is the measure appropriate for the purpose of ensuring the claimed goal?

And if yes:

2) is the measure necessary to attain the legitimate objective being pursued?

\subsubsection{How to perform the export restriction test}

The fact that Cassis De Dijon can be used as described above is more than just a theoretical observation. As explained in the previous section about import restrictions, the exception rule in Article 36 does cover "the protection of health and life of humans, animals or plants" but does not include environmental reasons in a broader sense to set up a national obstacle to trade (import and export). As Article 36 applies both to Article 34 (imports) and Article 35 (exports), case law under Article 36 
is relevant in both situations. Now, this means that if a national export ban is invoked on the grounds of environmental protection, it will be contrary to the Treaty, as environmental protection is not specifically stated in Article 36.

An export ban is per se directly discriminatory as it will - according to the wording in the case regarding horse meat mentioned above, 15/79, Groenveld:

provide a particular advantage for national production or for the domestic market of the State in question at the expense of the production or of the trade of other Member States.

Thus, a directly discriminatory export restriction can only be justified according to Article 36, which cannot justify the legislation for environmental reasons.

If the national legislation is only indirectly discriminatory or nondiscriminatory, the legislation will - all things being equal - be acceptable according to the Treaty.

If it is non-discriminatory, it will not fall under the scope of Article 35 in the first place. That is the case e.g. if national legislation imposes a general ban on distributing hazardous waste or other types of goods. This might constitute an obstacle to export, but as it is equally difficult to distribute on the internal market the legislation does not "provide a particular advantage for national production or for the domestic market of the State in question", and is not contrary to Article 35.

Finally, if the measure is indirectly discriminatory, the measure can both be justified according to Article 36 and according to the Cassis de Dijon doctrine's unlimited list of compelling reasons, e.g. the environment. In the previous example this could be the case if the distribution ban on hazardous waste was limited to, say, a distance of $200 \mathrm{~km}$ from the source. Here the ban imposes an advantage for the national production and is thus covered by Article 35. It is not directly discriminatory as the ban does not talk about "export" or the like. However, it is more likely that the domestic market will be within the $200 \mathrm{~km}$ distance than any foreign market, and therefore the legislation is indirectly discriminatory. Such a measure may be justified on the grounds of protecting the environment according to the Cassis de Dijon case. Similarly, a measure stating that a used TV set cannot be exported would be directly discriminatory and thus only acceptable if the reason is listed in Article 36. But if the measure states that a used TV must be sold only by certain retailers certified by the Member State, it would constitute an indirectly discriminatory measure. The reason for this is that the TVs will more likely only 
stay on the domestic market as no retailers outside this market will be certified by the state of origin. Such a measure can also be justified for environmental reasons in accordance with the principle of the Cassis de Dijon case.

\subsubsection{Sub-conclusion}

For the purpose of this report the conclusion can be drawn from the above that environmentally motivated national measures with an impact on exports can normally only be in accordance with the Treaty if they are either:

- Non-discrimatory.

- Indirectly discriminatory but acceptable due to a compelling reason for the protection of the environment and can pass the test on proportionality.

\subsection{The relevance of harmonisation}

Neither Article 34 nor Article 35 are applicable if EU legislation provides harmonisation of the measures necessary to achieve the specific objective, and recourse to Article 36 is no longer possible in that situation.

The reason for this is that there is no longer room for national legislation when harmonisation is in place, thus no conflict is possible regarding Article 34 or 35.

This means that no export or import ban can be invoked if the area is harmonised, no matter what type of justification etc. is cited by the Member State, as the entire purpose of EU harmonisation is to eliminate different national measures.

Moreover, the harmonisation instrument even precludes EU Member States from invoking Article 36 of the Treaty to justify a limitation of exports of goods to another EU Member State on the sole ground that, according to the first Member State, the second Member State is not complying with the requirements of an EU harmonising directive.

This could be the case if the EU legislation in fact pursues an objective which Article 36 is intended to protect, but does not lay down any procedure for monitoring their application or any penalties in the event 
of their breach. ${ }^{29}$ For instance, if a piece of EU legislation bans the use of artificial colour in food in order to protect human health, and Member State A fails to implement correctly, Member State B cannot prohibit import of the foodstuff from Member State A with reference to Article 36 and its acceptance on protection of human health. Member state B must nofify the Commission, and it might be the case that Member State A has violated the treaty when it comes to the obligation to implement, but Member State B cannot meet this violation with an import restriction.

In other words: National provisions contrary to EU harmonisation should not be examined according to the principles of free movement of goods in the Treaty but should instead simply be considered as provisions contrary to secondary EU legislation. This situation of conflict of EU law and national legislation must be dealt with according to the principle of supremacy of EU law. ${ }^{30}$

An example of the technique is this: The Montreal Protocol is ratified by the EU and as explained in chapter 7.2 EU regulation on substances that deplete the ozone layer implements the Montreal Protocol within the EU. In terms of harmonisation this means that if a Member State wishes to enact requirements or bans which exceed the requirements in EU regulation, a two-tier test applies: 1 ) is it in accordance with EU regulation on substances to set more ambitious goals than those aimed for in EU regulation? If the answer is no, there will be no trade barrier question. Instead, there is a situation where a national provision is contrary to secondary EU legislation. This situation of conflict between EU legislation and national legislation must be dealt with according to the principle of suprimacy of EU law. However, if the answer is yes, the question is then 2) are the exceeding requirements in accordance with the rules on trade of goods?

Below in chapter 5.5 we examine the relevance of harmonisation specifically with regard to the WEEE-directive.

\subsection{Case study - TFEU and the WEEE directive}

An example of harmonisation is the WEEE directive. The WEEE-directive is a minimum directive, meaning that the Member States can set more ambitious goals than those aimed for in the directive. See e.g. Article 7 (1) regarding collection rates. The directive became effective on 14 Feb-

${ }^{29} \mathrm{C}-5 / 94$ - Hedley Lomas.

${ }^{30} \mathrm{C}-6 / 64$ - Costa v ENEL. 
ruary 2014, so by that date countries without WEEE management should have implemented the directive and countries already having WEEE management schemes in place should adapt their national legislation to the directive. According to Article 14, "Information for users" paragraph 2 "Member states shall ensure that users of EEE in private households are given the necessary information about: the requirement not to dispose of WEEE as unsorted municipal waste and to collect such WEEE separately [...].

According to paragraph 5:

Member States may require that some or all of the information referred to in paragraphs 2,3 and 4 shall be provided by producers and/or distributors, e.g. in the instructions for use, at the point of sale and through public awareness campaigns. (Italic here).

Without the WEEE directive such a requirement would - even without thorough examination - be considered a measure having the equivalent effect of a quantitative restriction according to TFEU Article 34. It would be seen as a non-discriminatory "requirement for the product" (the directions on the information in the manual of the product) and thus subject to the test of compelling reason and proportionality according to Cassis de Dijon, if it applies to both foreign and domestic products. It would probably be accepted, as the requirement is non-discriminatory and can be justified according to the Cassis de Dijon doctrine, including the aim to protect the environment, and it would probably be considered proportional to pursue the aim in such a manner. The same is true for e.g. Article 4 directly introducing requirements for "product design".

However, these requirements are indeed part of the EU secondary legal framework and can - and must - therefore be implemented accordingly. The unhappy importer will not under any circumstances succeed in an Article 34 proceeding in these examples. However, as the WEEE directive is a minimum directive, it is as mentioned possible for the Member States to set more ambitious goals than those aimed for in the directive. This "gap" between the level provided by the directive and the higher national level is subject to scrutiny under TFEU Articles 34-36. The reason for this is that this gap is a solely national legislative measure - accepted in the directive, yes, but implemented without any EU requirement to do so.

We put down as a pre-requisite that no regulation on the internal market other than what directly follows from the WEEE directive is intended. Thus, trade with used EEE is suspected to be under no more obligations that already in place. 
According to the WEEE directive Article 23:

Member states shall carry out appropriate inspections and monitoring to verify the proper implementation of this Directive.

And it follows that those "inspections shall at least cover [...]".

This means that the following requirements are minimum requirements which - as described above - in principle leave a gap for the Member States to set up even more intensive inspections than those provided for in the directive. According to Article 23, (1)(b), the inspections must cover "shipments". "Shipments" is not defined in the WEEE directive but a definition is found in EU Regulation on shipments of waste, Article 2 (34) where "shipment" means the transport of waste destined for recovery or disposal which is planned or takes place: (a) between a country and another country; or other overseas countries and territories etc. This means that the required inspection as a minimum must be carried out as a result of a product's crossing of a border. According to the WEEE directive Article 23, (2) "Member States shall ensure that shipments of used EEE suspected to be WEEE are carried out in accordance with the minimum requirements in Annex VI and shall monitor such shipments accordingly". Thus, not only must a truck with used EEE be inspected by the border. If this inspection leads to suspect the used EEE to be WEEE, even more minimum requirements apply. According to the extra minimum requirements in Annex VI of the directive, the following applies in that situation: "In order to distinguish between EEE and WEEE, where the holder of the object claims that he intends to ship or is shipping used EEE and not WEEE, Member States shall require the holder to have available the following to substantiate this claim:[...]" and then follows a series of minimum requirements to declarations, invoices etc.

For instance: A truckload of old non-flat TV sets arrives at the border. National legislation must according to the WEEE directive as a minimum ensure that some of the truckloads are inspected. If the inspector discovers that a truck is loaded with used and old non-flat TVs, he will probably at least suspect the TVs to be WEEE rather than used EEE under the assumption that nobody in Europe in practice buys anything but flat-screen TVs these days. Then the minimum requirements in Annex VI apply, so that the inspector as a minimum must ensure that the holder of the truckload can provide documentation as specified in Annex VI.

As these are minimum requirements the Member States can aim for a higher level of protection. In that case: Would it be possible to make inspection easier by simply banning (either import or export of) all non- 
flat screens? In the absence of fully harmonising provisions at EU level, it is a starting point for the Member States to decide upon the level at which they want the safety in their territory. ${ }^{31}$ However, the gap between the paperwork requirements in the WEEE directive and a total import and export ban would be subject to scrutiny under Article 34 on import restrictions and Article 35 on export restrictions in the Treaty. In the TV example we are looking at a quantitative restriction as the number of allowed imported or exported TVs is 0 . Thus, the obstacle can only be justified according to Article 36. Then one must ask if the gap between the documentation requirements and the total ban on TVs is necessary in order for the protection of the health and life of humans, animals or plants? It will be difficult to prove that the exemptions requirements are met. As mentioned in the previous sections, the exceptions in the Treaty are to be interpreted narrowly, and WEEE does not seem to pose an immediate risk to the health or life of humans, animals or plants, rather it can be described as a risk to the environment in general and to natural resources. As described, Article 36 does not provide an exception on the grounds of the protection of the environment in a broader sense when it comes to quantitive and directly discriminatory measures. Moreover, the gap between the documentation requirements and a total ban would likely be seen as motivated by administrative reasons rather than protection of the environment by the ECJ. This is simply because it is much easier to ban it completely than to inspect and control. Administrative reasons do not even apply as exception under the Cassis de Dijon doctrine for a non-direct discriminary measure. The ECJ will probably note that already the harsh documentation requirements are indeed motivated by environmental reasons according to the preamble of TFEU, where it is stated:

The objectives of the Union's environment policy are, in particular, to preserve, protect and improve the quality of the environment.

Even if the reason was accepted either under Article 36 as regarded as protection of health etc. or accepted under Cassis de Dijon as an environmental measure, the measure would still have to pass the test on proportionality. That is to ask whether the measure is appropriate for the purpose of ensuring the claimed goal, and if yes whether the measure is necessary to attain the legitimate objective being pursued.

${ }^{31}$ Case C-110/05, Commission of the European Communities v the Italian Republic., para. 61. 
In the TV example with the total ban, both questions must be answered in the negative. A total ban on import or export of non-flat screens will not be appropriate in order to ensure a better environment if there is no such equivalent domestic ban on these products. In other words: The claimed danger maintains to exist the day after the ban is enacted.

One could argue that the WEEE directive internally dictates that a used TV set is handled environmentally correct because the directive sets up requirements for waste treatment of WEEE, thus there is no discrimination when imposing this kind of restriction on exports. This might be true if the export ban were actually equivalent with the requirement in the directive. However, this is not the case, as a total ban would go much further than dictated in the directive: A total export ban on non-flat TVs would hinder the trade of perfectly functionable used TVs as well and not only the trade of used TVs which are on their way to the bin. Thus, these TV sets will still be directly discriminated as the internal market does not prohibit sale or trade of such TVs.

Moreover, the ban is not necessary to pursue the goal of a safe environment as less trade-invasive measures can be thought of.

The latter should always be held up against the fact that the ECJ always looks for the least invasive obstacle to the trade of goods. A total ban is obviously the worst. Therefore the ECJ will come up with less invasive alternatives to a total ban: inspections, certifications of usability and/or other proof. In other words: Probably some of the same sorts of protection as already described in Annex VI of the WEEE directive. Thus, a total ban on non-flat screen TVs will be contrary - not to the WEEE directive but to the Treaty.

Another question could be if it was possible to require proof of functionality on all shipments of used EEE and not only those suspected of carrying WEEE; a sort of registration or notification procedure with regard to all used EEE shipments. Already Article 23 (1) in the directive requires as a minimum (some) shipments to be inspected. The inspection itself is therefore not only in coherence with the directive but a direct requirement. The requirements in Annex VI are also minimum requirements, thus proof of functionality in the order stated in the directive will be consistent with these minimum requirements and will not even constitute a TFEU Article 34 question.

The question left is therefore: If Article 23 (2) sets forth that only loads suspected of carrying WEEE can be meet with Annex VI requirements, can the EU Member States require more than provided in the directive? As mentioned above, the directive is a minimum directive leav- 
ing the option open to carry the goal of the directive even further. Thus, it is acceptable with regards to the directive to implement national measures requiring proof of functionality also for loads which are not suspected to carry WEEE. However, here Articles 34-36 apply once again. If the requirement only applies to imports or exports, it is not a quantitative restriction - as there is in principle no limit to the amount of goods possible to import or export - but it is indeed a directly discriminatory measure equivalent to such a quantitative restriction. No trade or shipment within the country will be under an obligation to notify or register loads of TV sets. Thus, such a measure will be directly discriminatory as it differs on the grounds of the nationality of the load.

It is a requirement to the product as the proof must ensure a certain quality of the goods. Again, Article 36 leaves - in its normal reading - no space for environmental issues, and even if it did, we would face the same proportionality problem as described above: It is not appropriate to test or require notification or registration of all cross-border shipments for proof of functionality in order to protect the environment if all domestic trucks can drive around in the Member State with pure loads of non-functional used EEE. It would be another situation if the same demand on test of functionality was placed on domestic trade with used EEE. It would then be a non-discriminatory measure; provided that the WEEE directive leaves space for such a measure, i.e. meaning that no EU harmonisation has been imposed covering the measure.

Thus, a requirement for proof of functionality or notification of registration requirements for all cross-border shipments which are not suspected of carrying WEEE will also be contrary - not to the WEEE directive but to the Treaty.

\subsection{Conclusion}

In order to impose an export ban motivated by environmental concerns which are not violating Article 35, the following two requirements must at least be met:

- There should be an equivalent restriction in the domestic market as well in order to make sure that the ban is not directly discriminatory. Otherwise the reason referring to the environment cannot justify the measure. 
- The measure must be appropriate for the purpose of ensuring the protection of the environment and must be necessary (there exist no other less trade-invasive possible measures) to attain the pursued goal of protecting the environment.

We may conclude that the WEEE directive leaves room for the EU Member States to set forth national regulation with a higher aim to protect the environment than the level described in the directive. However, such measures must comply with the obligations in the general rules on trade barriers in the Treaty. In the case study on national additional restrictive measures it was examined according to Articles 34-36 under the assumption that no domestic rules would be laid down with further requirements to the domestic trade. It was concluded that any ban, notification procedure or registration requirement that supersedes the requirements in the directive will be directly discriminatory and will therefore - under the ECJ's normal approach - not be justified as measures protecting the environment. The reason for this is that the Treaty leaves very little room for restriction to trade for environmental reasons in the broader sense as compelling reasons are limited to the protection of health and security etc. Moreover, if the ECJ (even) used other approaches and widened the scope of Article 36 to cover environmental measures, the measures would most likely not pass the test on proportionality. Therefore an additional requirement to the obstacles to trade already provided in the WEEE directive will, as no equivalent internal restrictions apply, constitute a breach of the Treaty. 



\section{Export restrictions on export outside the European Union}

\subsection{Introduction}

The rules in chapter 5 apply if the exporter chooses to export the goods to another EU country. If the exporter instead chooses to export the equipment to a country other than an EU Member State, the receiving country will most likely be a member of the WTO which has similar rules on barriers to trade as in the TFEU. 32

The purpose of the report does not suggest that the last receiving country of the goods will have the power to enact an import restriction on the goods. In fact, it would probably be an easier solution seen from the viewpoint of the readers of this report if such an import restriction was imposed as there would be no need to ban export in the country of origin as such an export restriction could also not be enforced. The situation here is therefore different than the one regarding the EU-to-EU trade above: Here, the only concern is if there are any obstacles to impose an export restriction. Thus, import restrictions under WTO will only be mentioned briefly in the following.

The legal framework of WTO is first and foremost 1. GATT (The General Agreement on Tariffs and Trade), which is a multilateral agreement regulating international trade, and 2. the TBT agreement (Agreement on Technical Barriers to Trade). While GATT provides the overall principles, the TBT agreement is more specifically detailed and prohibits technical requirements created in order to limit trade. The TBT agreement also sets forth a notification procedure, when a Member State intends to impose technical barriers and so on.

The purpose of GATT is - according to its preamble - the "[...] substantial reduction of tariffs and other barriers to trade and to the elimination of discriminatory treatment in international commerce [...]." There is an integrated connection between EU law and WTO law, as both the Member States and the EU itself are members of WTO, and the WTO 
agreements are thus regarded as an integral part of the legal order of the European Union. 33

All countries must adhere to their international obligations under the doctrine of "pacta sunt servanda" (agreements must be kept). However, if a country is in doubt about nuances of the limits of its obligations, it will have to rely on international tribunals if such exist in the area and if another country brings a case against it. Otherwise, their violations of international law are largely undetected. In the trade area (outside EU), these issues are resolved under the WTO dispute settlement mechanism, ${ }^{34}$ which is mandatory, binding and to some degree enforceable. 35

In a situation where e.g. the Basel Convention requires or merely urges signatories to enact trade bans, this would be an important factor in a WTO case. Doubts of nuances regarding the implementation of obligations stemming from the Basel Convention are less likely to be resolved in international dispute resolution systems - as with most environmental issues. Specifically the Basel Convention provides in art. 20 that if the Parties concerned cannot settle their dispute through the means mentioned in the convention, the dispute shall, if the Parties to the dispute agree, be submitted to the International Court of Justice.

\subsection{Dispute resolution}

It is important to note that the WTO is an intergovernmental organisation with a dispute resolution mechanism that resolves disputes on a purely bilateral basis in the sense that it is up to the individual WTO Members to bring cases against each other and to "enforce" WTO Law. This is different than in the EU where the EU Commission brings cases concerning non-conformity with EU Law to the EU Court system, which is also enforceable by other means than the bilateral tools available in international law. However, most importantly, for purposes of this anal-

\footnotetext{
${ }_{33}$ Birgitte Egelund Olsen et al, WTO Law - from a European perspective (Wolters Kluwer, 2012, Forlaget Thomson, 1. ed. 2006), p. 94.

${ }^{34}$ The World Trade Organization was established in 1995 by the founding act, see Final Act Embodying the Results of the Uruguay Round of Multilateral Trade Negotiations, Apr. 15, 1994, 33 I.L.M. 1125 (1994). The WTO Agreement establishes the WTO and all other agreements are annexed to this agreement, see the Marrakesh Agreement Establishing the World Trade Organization, Apr. 15, 1994, Legal Instruments Results of the Uruguay Round, 33 I.L.M. 1125 (1994), entered into force Jan. 1, 1995 [hereinafter the WTO Agreement].

35 The WTO dispute settlement mechanism is governed by Understanding on Rules and Procedures Governing the Settlement of Disputes, Apr. 15, 1994, WTO Agreement Annex 2, Legal Instruments - Results of the Uruguay Round, 33 I.L.M. 1125 (1994).
} 
ysis, the difference between the EU analysis and the WTO analysis, whilst legally resembling each other, a WTO case requires another WTO member to actually instigate a case. It takes a lot more of an independent state to do that than for the EU Commission that is charged with the job of overseeing implementation and adherence to EU Law. In addition, certain WTO members are more likely to bring cases than others. ${ }^{36}$ Whilst there is some scholarly discourse about strategic litigation in the WTO, it is probably safe to assume that unless somebody is losing money on not being able to export or import certain used EEE or some WEEE anymore, a WTO case about the legality of such a trade measure will not arise. If a case arises first rulings are made by "a panel" and "The Appellate Body" hears appeals from reports issued by the panel.

\subsection{WTO Legality of a used EEE Trade Ban}

If an EU Member State or the EU as a whole enacts an export barrier in the form of a ban of the exportation of certain used EEE; 37 some or all WEEE, and another WTO Member complains about this, a WTO case is likely to arise and the legality will be tested.

A complainant will normally invoke all relevant WTO Agreements, but in this case that may be different, as it may only be the GATT that applies to export barriers. ${ }^{38}$ The Panel will decide whether it will analyze the GATT or the TBT Agreement - or both - if both are invoked. The Appellate Body has in the past interpreted the TBT Agreement as a type of lex specialis Agreement to the GATT which means that the TBT Agreement would take precedence over GATT. ${ }^{39}$ However, in this instance it maybe that the lack of a prohibition of an export restriction in the TBT Agreement may prompt the complainant to refrain from invoking the TBT Agreement and rely on the Panel's historic lack of will to re-

\footnotetext{
${ }^{36}$ It is primarily the developed WTO Members that have the capacity to bring WTO cases, although the more developing countries also bring cases, see e.g. as an example of such a case Dispute DS457 https://www.wto.org/ english/tratop_e/dispu_e/dispu_by_country_e.htm

${ }^{37}$ Even if it is only one EU Member State that has a special law, it will be the EU Commission defending the measure anyway acting for the EU. This was seen in e.g. see Appellate Body Report, European Communities Measures Affecting Asbestos and Asbestos Containing Products, WT/DS135/AB/R (Sept. 18, 2000) [hereinafter EC - Asbestos $\mathrm{AB}]$.

38 See the General Agreement on Tariffs and Trade, Oct. 30, 1947, 55 U.N.T.S. 194 [hereinafter GATT 1947], which is now incorporated into GATT 1994, see the General Agreement on Tariffs and Trade, Apr. 15, 1994, WTO Agreement Annex 1A, Legal Instruments - Results of the Uruguay Round, 33 I.L.M. 1125 (1994) [hereinafter GATT 1994].

39 This was also the implicit conclusion in the in the latest case, see Appellate Body Report, European Communities - Measures Prohibiting the Importation and Marketing of Seal Products, WT/DS400/AB/R, WT/DS401/AB/R (May 22, 2014) [hereinafter EC-Seal Products], at chapter 4.
} 
frain from analysing agreements, even if obvious doubt existed as to their applicability. The TBT Agreement applies to "technical regulations", "standards" or "conformity assessment procedures" as laid down in the TBT Agreement, Annex 1. In order to be a "technical regulation", the Appellate Body has held that a measure has to apply to an identifiable group of products, lay down one or more characteristics of a product and compliance must be mandatory. 40

It is likely that a trade ban on certain types or all used EEE may lay down product characteristics. The case EC - Asbestos concerned a French ban on imports of products containing asbestos. ${ }^{41}$ The Appellate Body considered that "although formulated negatively - products containing asbestos are prohibited - the measure, in this respect, effectively prescribes or imposes certain objective features, qualities or "characteristics" on all products. That is, in effect, the measure provides that all products must not contain asbestos fibres." 42 The measure was therefore characterized as a technical regulation. Consequently, if the used EEE is therefore defined based on whether it consists of certain materials, it is likely to be a technical regulation and therefore a TBT. However, it could also be a TBT simply on the basis of the product characteristic that the product is used, or a technical description of the extent to which it is used.

There is, however, no provision that explicitly prohibits trade bans or quantitative restrictions in the TBT. TBT Article 2.2 is probably the most relevant provision with its prohibition of unnecessary obstacles to trade. This provision is, however, rarely used so it is not easy to predict how it would be interpreted. The provision reads:

"Members shall ensure that technical regulations are not prepared, adopted or applied with a view to or with the effect of creating unnecessary obstacles to international trade. For this purpose, technical regulations shall not be more trade-restrictive than necessary to fulfil a legitimate objective, taking account of the risks non-fulfilment would create."

The legal test is thus a two-tier analysis of 1) whether the objective is legitimate and 2) whether the technical regulation is not more trade restrictive than necessary. 43 The focus point of this analysis is thus the

\footnotetext{
${ }^{40}$ For further analysis of those criteria, see Appellate Body Report, European Communities - Measures Affecting Asbestos and Asbestos Containing Products, paras. 66-75, WT/DS135/AB/R (Sept. 18, 2000) [hereinafter EC - Asbestos AB]; Appellate Body Report, European Communities - Trade Description of Sardines, paras. 176195 WT/DS231/AB/R (Sep. 26, 2002), [hereinafter EC-Sardines AB]. 
"necessity" test, which stems both from the first and the second sentence of Article 2.2.44

The objective to prevent hazardous waste from spreading by hindering export of used products that at some point will become hazardous waste as a policy goal laid down in an international convention, will without any doubt fulfill the criteria as being a legitimate objective. This is the case in the Basel Convention. However, even without reference to a convention, such an objective would probably be considered legitimate. The necessity test in the sense of TBT Article 2.2 is more difficult to predict - in particular also because this test is not well-developed. However, a few things should be highlighted:

It will be relatively straight-forward to explain the degree of contribution the export restriction on used EEE that can become hazardous waste has on the legitimate objective; i.e. to prevent hazardous waste from spreading. ${ }^{45}$ Another type of analysis falling within the range of necessity tests in Article 2.2 is whether an alternative, less trade restrictive measure would be reasonably available. ${ }^{46}$ It is difficult to imagine that any other measure would fulfill the policy goal as effectively, in particular when the export restrictions are prescribed in an international convention, but also where this is not the case. Labelling would, for example, not prevent the spreading.

Another thing that should be noted is that it is - similarly discussed above regarding Article 34-36 in TFEU - advisable to enact similar national rules on the relevant used EEE and WEEE. This is not an explicit requirement in the necessity analysis in TBT Article 2.2, but it seems discriminatory not to do so. It should however be noted that the risk of WEEE spreading with exports is not identical to the national risk if, e.g., collection of WEEE is mandatory nationally (i.e. trade in WEEE may stop automatically if disposal is free of charge). The risk with used EEE is also different nationally if it cannot be exported; i.e., it cannot spread to countries without proper waste treatment. Relying on such arguments is, however, risky as it is likely a Panel and the Appellate Body may consider it discriminatory not to have similar national rules.

In conclusion, whilst it is clear that export restrictions on used EEE is creating a restriction on international trade, it may be found to fulfill the legitimate objectives and thus not violate TBT Article 2.2 in the event the Panel should decide the export restrictions were in fact technical regula-

\footnotetext{
${ }^{44}$ See Appellate Body Reports, United States - Certain Country of Origin Labelling (COOL) Requirements, WT/DS384/AB/R /WT/DS386/AB/R, adopted 23 July 2012, para. 374.

${ }^{45}$ See id., at para. 319.

46 See id.
} 
tions. The important message is, though, that the export restriction should be coupled with domestic rules also. In addition, it may be worth analysing extensively the difference between prohibiting WEEE and specific types of used EEE before enacting such measures as the domestic corresponding measure may be different and the risk involved should be clarified. The reason for this is - as indicated earlier - that if the domestic market and the export market are treated differently, it will be discriminatory. However, this is only the case if the conditions are the same: It is only discriminatory to treat equal things differently or to treat different things equally.

\subsubsection{Article XI and XX}

GATT Article XI:1 concerns "General Elimination of Quantitative Restrictions". It reads:

No prohibitions or restrictions other than duties, taxes or other charges, whether made effective through quotas, import or export licences or other measures, shall be instituted or maintained by any contracting party on the importation of any product of the territory of any other contracting party or on the exportation or sale for export of any product destined for the territory of any other contracting party.

GATT Article III.4 provides the principle of "national treatment". It reads:

The products of the territory of any contracting party imported into the territory of any other contracting party shall be accorded treatment no less favourable than that accorded to like products of national origin in respect of all laws, regulations and requirements affecting their internal sale, offering for sale, purchase, transportation, distribution or use. The provisions of this paragraph shall not prevent the application of differential internal transportation charges which are based exclusively on the economic operation of the means of transport and not on the nationality of the product.

GATT Article XI:1 contains a specific prohibition against quantitative restrictions, including $100 \%$ quotas targeting both import and export restrictions in general. ${ }^{47}$ This provision has already been subject to several cases concerning export restrictions. ${ }^{48}$ It should be noted that

\footnotetext{
${ }^{47}$ Non-automatic export licenses are e.g. also a violation of Article XI:1, see Panel Report, India - Measures Affecting the Automotive Sector, WT/DS146/R, WT/DS175/R and Corr.1, adopted 5 April 2002, para. 7.273 ${ }^{48}$ See e.g., Id; Panel Reports, China - Measures Related to the Exportation of Various Raw Materials, WT/DS394/R / WT/DS395/R /WT/DS398/R / and Corr.1, adopted 22 February 2012, as modified by Appellate Body Reports WT/DS394/AB/R / WT/DS395/AB/R / WT/DS398/AB/R; Panel Report, China Measures Related to the Exportation of Rare Earths, Tungsten, and Molybdenum, WT/DS431/R,
} 
there exist some scholarly debates about whether Article XI:1 applies to situations where a total domestic ban also exist. For import bans that may be the case, as this is then seen as an internal measure falling under GATT Article III.

For export bans it is unclear whether it will have any resonance with the Panels, but it is worth trying. One can for example draw parallels to a situation where illegal drugs are attempted to be exported. An export measure coupled with an internal measure in this fashion may be considered an internal measure under Article III for that reason. However, whether this escapes the disciplines under Article XI:1 is difficult to predict and thus not a defense to be relied upon too much.

When a measure is found in violation of a substantive obligation such as Article XI:1, it can be justified under the General Exceptions in GATT Article XX. Contrary to the similar provision on TFEU Article 36, the exceptions in Article XX do cover environmental protection measures with the aim to conserve natural resources:

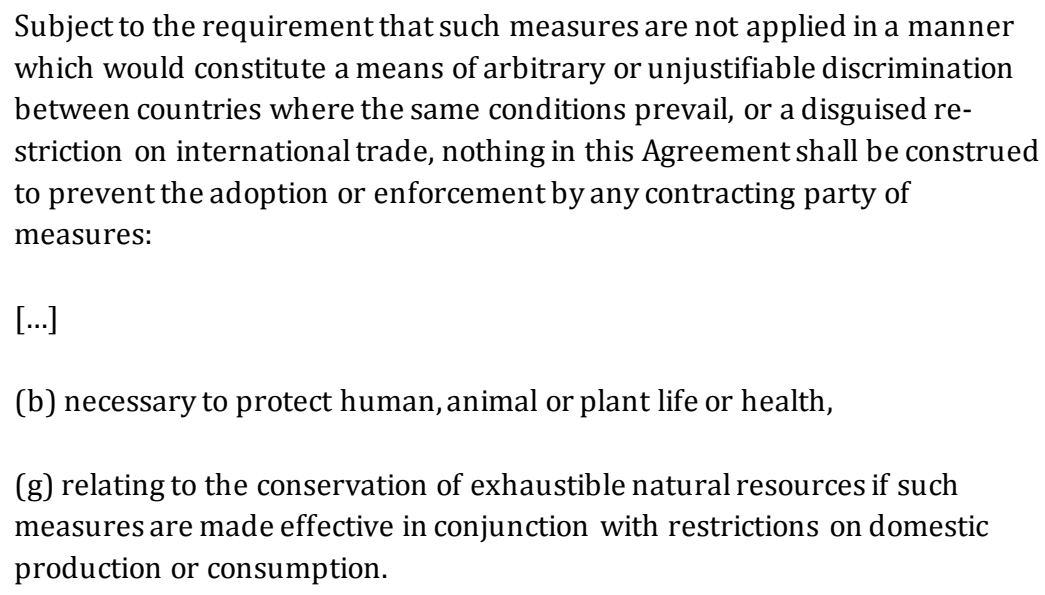

The application of Article XX of the GATT is a two-step exercise where the first step is to satisfy all the requirements in one of the paragraphs in Article XX and the second to satisfy the requirements in what is commonly called the "Chapeau" or introductory clause of Article XX.

The first step of the analysis of Article XX of the GATT is to categorize the measure within the policy scope of sub-paragraph (b) or (g). Historically, sub-paragraph (g) is considered "easier" to satisfy than (b) given it has a slightly different test than the "necessity" test in sub-paragraph 
(b). ${ }^{49}$ This appeared quite problematic, as protection of humans did not fall under paragraph (g), unless, as has been noted with humour, "mankind is itself an exhaustible natural resource." 50 The Appellate Body has, however, seemingly sought to cure this problem by modifying the "necessity" test in sub-paragraph (b) in the case Brazil - Retreaded Tyres. The Appellate Body in that case clarified that the "necessity" test requires that the measure "materially contribute" to achieve the policy goal in issue. This is closer to the correlating test in paragraph (g) "relating to", which historically has been understood to require that the measure be "primarily aimed at" the policy goal in issue.

It is the defending party that invokes the exception and bears the burden of proof, and it may be worth understanding that the respondent may have some control over which sub-paragraph that is analysed as the panels so far have applied the paragraphs invoked by the parties in that order that they are invoked without analysing the point further. ${ }^{51}$

As to the necessity test in sub-paragraph (b), it resembles the analysis from TBT Article 2.2. The test is to determine what is necessary to achieve the policy goal: to protect human, animal or plant life or health. If it goes too far, the necessity test is not passed. Here, all factors will be weighed and balanced (i.e. analysed) and it will therefore be of importance that the policy stems from an international convention. ${ }^{52}$ If that test is passed, the next will be whether an alternative measure would be reasonable available. ${ }^{53} \mathrm{It}$ is for the complaining party to raise alternative measures. Again, as highlighted under the TBT analysis, it is difficult to imagine an alternative measure that would seem acceptable to the Panel given the original measure seems to be the only way to do things in this area. This argument especially holds truth if it concerns a practice condoned by an international convention since this would underline the fact that there is worldwide acceptance of what the appropriate measures are. Finally, the same caveats and concerns regarding corresponding domestic measures are present in this analysis.

\footnotetext{
${ }^{49}$ See Appellate Body Report, Korea - Measures Affecting Imports of Fresh, Chilled and Frozen Beef, WT/DS161/AB/R, WT/DS169/AB/R (Dec. 11, 2000), at paras. 161, and accompanying footnote [hereinafter Korea-Beef AB].

${ }^{50}$ Arthur E. Appleton, "Shrimp/Turtle: Untangling the Nets", 2. J. Int'l Econ. L. (1999) 477, 483.

${ }^{51}$ See Laura Nielsen, The WTO, Animals and PPMs, 192-5 (2007).

52 See e.g., Appellate Body Report, China - Measures Affecting Trading Rights and Distribution Services for Certain Publications and Audiovisual Entertainment Products, WT/DS363/AB/R, adopted 19 January 2010, para. 242.

53 See e.g., id., at para. 246.
} 
The related to and in conjunction with test in sub-paragraph (g) resembles the necessity test but may fall slightly different and as mentioned, more lenient. Consequently, it seems highly likely that a Panel will accept that the export restrictions contribute materially or there is a close and genuine relationship to the policy goal; i.e. preservation of the exhaustible natural resource: nature. ${ }^{4}$ What is interesting is that sub-section (g) requires an internal effort to be coupled with the export restriction. 55 This, therefore - again - points to the fact that it is highly recommendable that an export restriction by the EU as a whole or an individual EU Member State is coupled with corresponding internal measures.

The "Chapeau analysis", which is a test of the application of the measure, is a final test to ensure that the exceptions are not abused. The Chapeau consists of three criteria: "arbitrary discrimination between countries where the same conditions prevail"; "unjustifiable discrimination between countries where the same conditions prevail"; and "disguised restriction on international trade". In situations where a total ban applies equally to all WTO members, it is difficult to find problems of discrimination, but they may arise. The Panel in another case concerning export restrictions commented extensively on the purpose of such an analysis:

[N]o WTO provision suggests that the purpose of WTO disciplines on export restrictions is to equalize Members' access to goods and resources. The WTO disciplines on justifiable trade restrictions are not redistributive; instead, they seem to aim for the maintenance of what the relative market situation would be absent the challenged restriction. ${ }^{56}$

This means that the general idea of the Chapeau analysis is not to harmonise the sovereign Member States' national legislation on the trade of goods, but to eliminate discrimination and arbitrariness of different types. It is therefore very important to design a restricting measure so it does not discriminate or is arbitrary in any way. The comparison is this: the products that might be chosen to be prohibited vis-à-vis those that are not intended to be prohibited in order to review whether a measure is discriminatory and/or arbitrary. Whilst this is not formally a test un-

\footnotetext{
${ }^{54}$ See e.g., Appellate Body Report, China - Measures Related to the Exportation of Rare Earths, Tungsten, and Molybdenum, WT/DS431/AB/R, WT/DS432/AB/R, WT/DS433/AB/R, adopted 2 September 2014, para. 5.90. ${ }^{55}$ See e.g., id., at para. 5.91.

${ }_{56}$ Panel Report, China - Measures Related to the Exportation of Rare Earths, Tungsten, and Molybdenum, WT/DS431/R, WT/DS431/R/Add.1, WT/DS432/R, WT/DS432/R/Add.1, WT/DS433/R, WT/DS433/R/Add.1, adopted 2 September 2014, at para. 7.360.
} 
der the Chapeau analysis, it can quickly become one if the importing country relies heavily on one type of product and not another. So these are things to consider when designing the measure. ${ }^{57}$

\subsection{Case study - WTO and the WEEE-directive}

Under EU law we concluded that, in the absence of fully harmonising directives at EU level, it is as a starting point up to the Member States to decide which safety level they want in their territory. But the analysis also showed that the gap between the paperwork requirements in the WEEE-directive concerning shipments of used EEE and a total import and export ban, would be subject to scrutiny under Article 34 on import restrictions and Article 35 on export restrictions in the Treaty.

In the TV example we were looking at a quantitative restriction as the number of allowed imported or exported TVs would be 0 . Thus, the obstacle could only be justified according to Article 36 and, therefore, the narrow exceptions regarding the health and life of humans, animals or plants. We suggested that it would be difficult to prove the exemption requirements fulfilled as the exceptions in the Treaty are to be interpreted narrowly, and WEEE does not seem to pose an immediate risk to the health or life of humans, animals or plants, but rather only a risk to the environment in general and to the natural resources.

Under WTO, a ban against export of funtional TV sets does not necessarily constitute a violation of WTO law. In Brazil - Retreaded Tyres, the ban concerned import of used tires. Brazil justified its import restrictions on the basis of environmental and human health concerns and argued that tires contain highly combustible and polluting materials, and that tire incineration releases toxic gases and contaminates Brazil's soil, water and air. For these reasons, a number of developing countries, including Albania, Algeria, Argentina, Bangladesh, Bahrain, Cambodia, Colombia, Ecuador, The Philippines, Jordan, Macedonia, Morocco, Mexico, Nigeria, New Zealand, Pakistan, Peru, Thailand, Sri Lanka, Uganda and Venezuela, banned or restricted back then the imports of used or retreaded tires. In Brazil - Retreaded Tyres, this was, really without any further explanations, acceptable. The situation seems comparable as not all imported tires would be considered waste. At least some of them could be retreaded tires even though it might only be once. In Brazil -

${ }^{57}$ See e.g., Appellate Body Report, Brazil - Measures Affecting Imports of Retreaded Tyres, WT/DS332/AB/R, adopted 17 December 2007, at para. 232. 
Retreaded Tyres it was a problem that the ban did not apply for partners in a trade agreement with the other South American countries (the socalled "MERCUSOR exemption"). The Appellate Body found:

that the MERCUSOR exemption would result in the import ban being applied in a manner that constitutes unjustifiable discrimination and a disguised restriction on international trade only to the extent that it results in volumes of imports of retreaded tyres that would significantly undermine the achievement of the objective of the import ban

Therefore it might be reasonable to conclude that if it is not consistent with the TFEU with such a wide ban so that it will not apply for EU Member States, it will also be inconsistent according to WTO law.

The answer could perhaps be a certification scheme so that used TV sets could be exported to countries with, e.g., a ban on export of used EEE or requirements for disposal, a similar restriction of use domestically as for exports, etc. However, the problem is that such certification schemes are often very hard to administrate.

\subsection{Conclusion}

There seems to be no restrictions under WTO Law that prevents or should prevent either an individual EU Member State or the EU as a whole from enacting export restrictions on used EEE or WEEE. It seems highly likely that such measures, provided they are designed in a nondiscriminatory manner and coupled with an internal measure, will survive the relevant WTO tests.

It is, however, advisable to analyse extensively how to choose which types of used EEE that should be prohibited, and how the corresponding domestic measure should be designed before enacting such. For instance, if the measure is construed so that it violates TFEU in a way so it is determined that it should not apply in the EU, this can be inappropiate according to WTO even though the measure itself might be isolatelly acceptable according to WTO. As stated, analysing extensively the difference between prohibiting one product and not another while clarifying the risk involved is crucial to determining if there is a corresponding domestic measure. This risk analysis will be an important aspect of a WTO case and the difference between WEEE and used EEE should be very clearly analysed. 



\section{Montreal Protocol on CFCs and EU Regulation on Substances that Deplete the Ozone Layer}

\subsection{Introduction}

One way to restrict the free movement of used EEE is to focus on the regulation of substances.

The focus in environmental legislation has for many years been directed towards restriction of the production and use of hazardous substances, and several conventions have been adopted in the efforts.

The Montreal Protocol is focused on substances that deplete the ozone layer and may serve as a basis for export restrictions of used EEE, if the substances comprised by the rules of the convention are found in the used EEE.

\subsection{The Montreal Protocol}

The Vienna Convention on Protection of the Ozone Layer was adopted in 1985 and entered into force on 22 September 1988. The objectives of the Convention were for parties to promote cooperation by means of systematic observations, research and information exchange on the effects of human activities on the ozone layer and to adopt legislative or administrative measures against activities likely to have adverse effects on the ozone layer.

The Vienna Convention did not require countries to take concrete actions to control ozone depleting substances. Instead, in accordance with the provisions of the Convention, the countries of the world agreed to the Montreal Protocol on Substances that Deplete the Ozone Layer under the Convention to advance that goal.

The Montreal Protocol on Substances that Deplete the Ozone Layer was designed to reduce the production and consumption of ozone de- 
pleting substances in order to reduce their abundance in the atmosphere, and thereby protect the Earth's fragile ozone layer.

The original Montreal Protocol was adopted on 16 September 1987 and entered into force on 1 January 1989. On 16 September 2009, the Montreal Protocol achieved universal participation.

The EU regulation on substances that deplete the ozone layer implements the Montreal Protocol within the European Union. ${ }^{58}$

\subsection{EU regulation on substances that deplete the ozone layer}

\subsubsection{Ban on export}

The EU regulation establishes a ban on export of controlled substances, and products and equipment containing or relying on so-called controlled substances, cf. Art. 17, section 1.59

Controlled substances are the substances listed in Annex I of the regulation, cf. Art. 3, 3). In Annex I is found, e.g., CFCs, which are often used for cooling purposes in used EEE.

To the extent that used EEE contains ozone-depleting substances, the used EEE will be comprised by the ban mentioned above. EU Member States can and are obliged to enforce this ban.

A number of exemptions apply to the ban:

- Controlled substances to be used for essential laboratory and analytical uses referred to in Art. 10 .

- Controlled substances to be used as feedstock.

- Controlled substances to be used as process agents.

- Products and equipment containing or relying on controlled substances produced in accordance with Art. 10, section 7 or imported under item (h) or (i) of Art. 15, section 2.

\footnotetext{
${ }^{58}$ Regulation (EC) No. 1005/2009 of the European Parliament and the Council of 16 September 2009 on substances that deplete the ozone layer.

${ }^{59}$ Export is defined as: "the exit from the customs territory of the Community, in so far as the territory is covered by a Member State's ratification of the Protocol and by this Regulation, of substances, products and equipment covered by this Regulation which have the status of Community goods or the re-export of substances, products and equipment covered by this Regulation if they have the status of non-Community goods", cf. Art. 3, 19). Thus, only export outside the EU is comprised by the ban.
} 
- Recovered, recycled or reclaimed halons stored for critical uses referred to in Art. 13, section 1, by undertakings authorised by the competent authority of a Member State and products and equipment containing or relying on halon to satisfy critical uses.

- Virgin or reclaimed hydro chlorofluorocarbons for uses other than destruction.

- Metered dose inhalers manufactured with chlorofluorocarbon, the use of which has been authorised on the basis of Art. 3, section 1, of Regulation (EC) No. 2037/2000.

In the case that a piece of used EEE falls under one or more of these exemptions export of this particular type of used EEE may be allowed, see section 8.3.2.

\subsubsection{Licensing exports}

Under Art. 17, sections 3 and 4, the EU Commission may authorise an export if it is subject to one of the exemptions mentioned above.

Also, export of products and equipment containing CFCs, where it is demonstrated that, in view of economic value and the expected lifetime of the specific goods, the ban on export would impose a disproportionate burden on the exporter, can be allowed if licensed. ${ }^{60}$ Such export licence must, however, be requested by the competent authority of the Member State in question. 61

In accordance with Art. 18 of the regulation, the EU Commission has set up an electronic licensing system for issuance of export permits. ${ }^{62}$

Art. 18, section 3, sets out the requirements for an application for export. Detailed information must be provided, including names and addresses of the exporter, the countries of import and export, type and character of the product, purpose of export, time and place, etc. The EU Member States are also given access to demand any further information considered necessary.

The EU Commission may reject the application for export, if any of the relevant obligations under the regulation is not complied with, cf. Art. 18, section 6. Rejection is also possible where the competent author-

\footnotetext{
${ }^{60}$ Except re-exports subsequent to transit through the customs territory of the Community, temporary storage, customs-warehousing or free zone procedure, as referred to in Regulation (EC) No 450/2008, provided that the re-export takes place not later than 45 days after the import.

${ }^{61}$ A specific procedure described in Articles 4 and 7 of Decision 1999/468/EC applies with regard to the provisions of Art. 8 thereof, cf. Art. 25, section 2, of the regulation.

$62 \mathrm{http}: / /$ ec.europa.eu/clima/policies /ozon e/ods/index_en.ht m
} 
ities of the importing country have informed the Commission that the import of the controlled substance would constitute a case of illegal trade, or would adversely impact on the implementation of control measures of the importing country in place to comply with its obligations under the Montreal Protocol or would lead to an excess of the quantitative limits under the Montreal Protocol for that country, cf. Art. 18, section 6, litra b).

The EU Commission provides a copy of each licence to the competent authority in the Member State concerned, cf. Art. 18, section 7.

\subsection{Conclusion}

The Montreal Protocol and EU regulation on substances that deplete the ozone layer contain a strong restriction regime. It constitutes both a ban on export of used EEE containing these substances and also requirements for obtaining an export licence if the given export falls under one of the exemptions to the ban. 


\section{Stockholm Convention and EU regulation on persistent organic pollutants}

\subsection{Introduction}

As seen in the previous chapter about the Montreal Protocol, one way to restrict the free movement of used EEE is to focus on the regulation of hazardous substances. While the Montreal Protocol focuses on the CFCs posing a risk to the ozone layer, the focus of the Stockholm Convention is on pollutants that persist in the environment, bio-accumulate through the foodchain, and pose a risk to human health and the environment.

While the Montreal Protocol has used EEE as a specific target, the Stockholm Convention is more generally focusing on the pollutants themselves.

\subsection{The Stockholm Convention}

The Stockholm Convention on Persistent Organic Pollutants (POPs) was adopted at a Conference of Plenipotentiaries on 22 May 2001 in Stockholm, Sweden. The Convention entered into force on 17 May 2004.

The Stockholm Convention regulates the import and export of the intentionally produced chemicals listed in Annexes A and B of the convention. EU regulation on persistent organic pollutants implements the Stockholm Convention within the European Union. ${ }^{63}$

${ }^{63}$ Regulation (EC) no. 850/2004 of the European Parliament and of the Council of 29 April 2004 on persistent organic pollutants and amending Directive 79/117/EEC with later amendments. 


\subsection{EU regulation on persistent organic pollutants}

Art. 3, section 1, of the regulation establishes a ban on the production, placing on the market and use of substances listed in Annex I of the EU regulation.

Substances listed in Annex II can only be subject to production, placing on the market and use in accordance with the restrictions stated in the Annex. However, no substances have yet been listed in Annex II.

Both the ban and the limitations apply to substances found in articles as defined in Art. 2, litra b:

"article" means an object composed of one or more substances and/or preparations which during production is given a specific shape, surface or design determining its end use function to a greater extent than its chemical composition does.

As used EEE would usually fall under this definition of "article", the ban and the limitations in Art. 3, sections 1 and 2, will apply to used EEE containing the substances in Annexes I and II. ${ }^{64}$

Placing on the market is defined in Art. 2, litra a:

"placing on the market" means supplying or making available to third persons against payment or free of charge. Imports into the customs territory of the Community shall also be deemed to be placed on the market.

The definition is interpreted as a ban on export of articles containing substances listed in Annex I.

A number of exemptions apply, cf. Article 4.

\subsection{Conclusion}

Export of used EEE will in most cases include making the used EEE available to a third party usually against payment. Thus, in such cases, the used EEE will be placed on the market in the sense of the EU regulation.

If substances found in the used EEE are listed in Annex I of the regulation, the ban on placing it on the market will apply and is to be considered a ban on export. The ban may be directly enforced on the basis of the provisions of the EU regulation.

${ }^{64}$ EEE comprised by the RoHS-directive is exempted from the POP-rules. The RoHS-directive does not apply to used EEE, as it - per definition - cannot be made available on the market for the first time. 


\section{Dansk sammenfatning}

Det estimeres, at mellem 50.000-100.000 tons brugt elektrisk og elektronisk udstyr eksportes ud af de nordiske lande hvert år. Denne mængde består af brugt udstyr, som eksporteres til genbrug, men sandsynligvis indeholder den også store mængder af elektronikaffald forklædt som brugt udstyr. Der er stort ønske om at finde virkemidler, der kan hindre denne uønskede eksport af elektronikaffald, fordi det giver store miljømæssige udfordringer i de lande, som modtager affaldet.

Formålet med projektet har været at undersøge de juridiske muligheder for at etablere restriktioner (forbud) på eksport af særlige typer brugt elektrisk og elektronisk udstyr, f.eks. på baggrund af indhold af farlige stoffer, højt energiforbrug eller begrænset markedsværdi.

Fokus i projektet har været på gældende miljøregulering og handelsregulering, som er blevet evalueret i forhold til at identificere hvorvidt der er i disse reguleringsregimer er juridisk basis for at etablere restriktioner på eksport af brugt elektrisk og elektronisk udstyr. Analysen fokuserer på handelsregulering i relation til det indre marked i EU og WTO-reglerne, som regulerer handel mellem lande globalt.

Projektet konkluderer, at affaldsregulering har meget begrænsede muligheder for at etablere restriktioner på eksport af brugt elektrisk og elektronisk udstyr. I forhold til handelsregulering er konklusionen, at det ikke kan udelukkes, at det er muligt at etablere sådanne restriktioner uden at komme i konflikt med hhv. det indre marked og WTO-reglerne. 



\section{Literature}

Legislation, etc.

Directive 2012/19/EU of the European Parliament and of the Council of 4 July 2012 on waste electrical and electronic equipment (WEEE).

Directive 2008/98/EU of the European Parliament and the Council of 19 November 2008 on waste and repealing certain directives.

Regulation (EC) no. 1013/2006 of the European Parliament and the Council of 14 June 2006 on shipments of waste as amended.

Regulation (EC) No. 1005/2009 of the European Parliament and the Council of 16 September 2009 on substances that deplete the ozone layer.

Regulation (EC) No 450/2008.

Regulation (EC) no. 850/2004 of the European Parliament and of the Council of 29 April 2004.

Decision 1999/468/EC.

Final Act Embodying the Results of the Uruguay Round of Multilateral Trade Negotiations, Apr. 15, 1994.

Rules and Procedures Governing the Settlement of Disputes, Apr. 15, 1994.

Marrakesh Agreement Establishing the World Trade Organization, Apr. 15,1994,

Legal Instruments - Results of the Uruguay Round, 1. January 1995.

General Agreement on Tariffs and Trade, Oct. 30,1947.

General Agreement on Tariffs and Trade, Apr. 15, 1994.

\section{Cases from the European Court of Justice}

C-6/64 Costa v ENEL.

C-8/74 Dassonville.

C-120/78, Rewe-Zentral.

C-206/88.

C-207/88 Vessoso and Zanetti.

C-2/90 The Commission v Belgium.

C-267/91 Keck.

C-268/91 Mithouard.

C-5/94 Hedley Lomas.

C-203/96, Chemische Afvalstoffen Dusseldorp.

C-418/97.

C-419/97 (ARCO). 
C-379/98, PreussenElektra AG.

C-9/00 Palin Grant Oy.

C-1/03 van der Walle.

C-110/05, Commission of the European Communities v the Italian Republic.

C-142/05, Åklagaren v Percy Mickelsson and Joakim Roos.

C-194/05.

C-252/07 Thames Water.

C-456/10, ANETT.

\section{Instructions and Reports}

Appellate Body Report, European Communities - Measures Affecting Asbestos and Asbestos Containing Products, WT/DS135/AB/R (Sept. 18, 2000). [In-text reference: (EC - Asbestos AB)].

Appellate Body Report, European Communities - Trade Description of Sardines. (Sept. 26, 2002). [In-text reference: (EC - Sardines AB)].

Appellate Body Report, European Communities - Measures Prohibiting the Importation and Marketing of Seal Products, WT/DS400/AB/R, WT/DS401/AB/R. (May 22, 2014). [In-text reference: (EC - Seal Products)].

Appellate Body Report, European Communities - Measures Affecting Asbestos and Asbestos Containing Products, WT/DS135/AB/R. (Sept. 18, 2000).

Appellate Body Report, China - Measures Affecting Trading Rights and Distribution Services for Certain Publications and Audiovisual Entertainment Products. (January 19,2010).

Appellate Body Report, China - Measures Related to the Exportation of Rare Earths, Tungsten, and Molybdenum. (Sept. 2, 2014).

Appellate Body Report, Korea - Measures Affecting Imports of Fresh, Chilled and Frozen Beef. (December 11, 2000). [In-text reference: (Korea - Beef AB)]

Body Report, Brazil - Measures Affecting Imports of Retreaded Tyres. (Sept. 11, 2007).http://ec.europa.eu/clima/policies/ozone/ods/index_en.htm

Dispute DS457 https://www.wto.org/english/tratop_e/dispu_e/ dispu_by_country_e.htm

European Commission - Guidance on the interpretation of key provisions of Directive 2008/98/EC on waste.

Internal note for the WEEE-group under the Nordic Council of Ministers on estimated future amounts of WEEE in the Nordic countries (not published) (2014).

Miljøstyrelsen. (2000). EU, Danmark og miljøreglerne. Arbejdsrapport fra Miljøstyrelsen, 7/1999,2000. (http://mst.dk/service/publikationer/publikationsarkiv/ 2000/feb/eu-danmark-og-miljoereglerne/). [In-text reference: (EU, Danmark og miljøreglerne, (http://mst.dk/service/publikationer/publikationsarkiv/2000/ feb/eu-danmark-og-miljoereglerne/))].

Panel Report, United States - Measures Affecting the Production and Sale of Clove Cigarettes. (April 24, 2012). 
Panel Report, India - Measures Affecting the Automotive Sector. (April 5 2002).

Panel Report, China - Measures Related to the Exportation of Rare Earths, Tungsten, and Molybdenum. (Sept. 2014).

Revised correspondents' guideline no. 1.

WTO Agreement Annex 1A, Legal Instruments - Results of the Uruguay Round. (1994). [In-text reference: (GATT 1994)].

\section{Books}

Nergaard, Ulla \& Nielsen, Ruth. (2010). EU Ret. (6. rev. udgave). Thomson.

Olsen, Birgitte Egelund et al. (2012,1. ed. 2006). WTO Law - from a European perspective. Wolters Kluwer, Forlaget Thomson, 1. ed.

\section{Articles}

Appleton, Arthur E. (1999). Shrimp/Turtle: Untangling the Nets.J Int Economic Law 2 (3):477-496.doi: 10.1093/jiel/2.3.477.

Nielsen, Laura. (2007). The WTO, Animals and PPMs. Brill.

Sommer, Tine. (1998). Udførselsrestriktioner og miljøhensyn. Juristen nr. 10. 
Ved Stranden 18

DK-1061 Copenhagen K

www.norden.org

\section{Restrictions on export of used EEE}

The purpose of the report is to clarify the legal possibilities of restricting export of certain types of used EEE due to e.g. content of hazardous substances, energy consumption and/or limited market value.

The focus is current environmental regulation and trade regulation which have been evaluated in order to identify if they can serve as the legal basis for setting restrictions on export.

The analysis concentrates on the legal framework of trade within the rules of the internal market in the EU and the legal concept of the WTO that regulates trade between countries worldwide.

The report concludes that waste regulation has very limited possibilities in regards to restricting export of used EEE. In regards to trade restrictions, it cannot be ruled out that such restrictions can be adopted in accordance with the rules of the internal market in the EU and the legal concept of WTO.

TemaNord 2015:581

ISBN 978-92-893-4419-7 (PRINT)

ISBN 978-92-893-4420-3 (PDF)

ISBN 978-92-893-4421-0 (EPUB)

ISSN 0908-6692

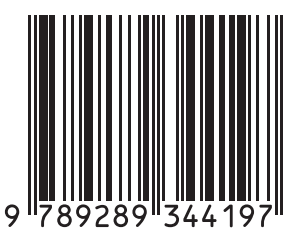

